\title{
Reconsidering 'Tokens': The Neolithic Origins of Accounting or Multifunctional, Utilitarian Tools?
}

\author{
Lucy E. Bennison-Chapman
}

Received 22 November 2017; Accepted 23 September 2018; Revised 23 August 2018

The origin of record keeping is a key question in the development of social complexity and specialized economies, representing the first step towards the emergence of written communication. Yet the precursors of the world's earliest writing and its initial stages of development remain little understood. Small, geometric clay objects ('tokens') appear in the tenth millennium cal. BC, the start of the Neolithic in West Asia, prevailing into the first millennium. It is largely assumed that from their inception clay objects played a crucial role in record keeping, directly evolving into the world's earliest known writing. Utilizing new and previously unpublished Neolithic data comprising almost individually studied 3000 objects, accompanied by information from 56 further Neolithic sites, this article investigates the meaning of Neolithic 'tokens'. Analysis proves the basis of their predominant interpretation to be incorrect; clay objects appear earlier than previously recognized and are not a necessary component of Neolithic agro-pastoral villages. 'Tokens' were multi-functional artefacts; even within a single site clay objects performed multiple roles. Though likely used in simple counting activities, this was not limited to the accounting of agricultural produce. Nor was counting the sole function of clay objects in the Neolithic. Clay objects were not created to administer agricultural produce and there is no evidence to suggest that in the Neolithic they formed part of a unified symbolic system. 


\section{Introduction}

The emergence of record keeping was a key social and economic development, allowing for the appearance of specialized economies and social complexity. Record keeping represents the first step towards the creation of writing, an apparatus which had a huge and longstanding impact on society, enabling the emergence of civilization as we know it today. The world's earliest known written script, cuneiform, emerged in the city-states of south Mesopotamia in the latter part of the fourth millennium calibrated BC (henceforth 'BC') (Cooper 2004; Damerow 2006; Englund 2004; Houston 2004; Michalowski 1994; 1990; Nissen 1986; Nissen et al. 1993; Vallat 1986; Woods 2010). Yet the precursors of cuneiform and the initial stages of its development remain unclear. Simple, small geometric-shaped clay objects appear in the archaeological record of West Asia from the early Neolithic period (c. tenth millennium $B C$ ), initially found at a small number of sites across the region (e.g. PPNA Jericho, Sheikh-e Abad and Çayönü) (Fig. 1; Broman Morales 1990; Kenyon \& Holland 1983, 356, 815, fig. 367.6; Matthews et al. 2013, 140, 141, 142, table 11.5). By the Late Neolithic (c. seventh and sixth millennium BC), clay objects are present in abundance at a large number of sites, yet still remain absent at others. It is generally assumed that from their inception in the Neolithic period, these clay objects, or 'tokens', played a crucial role in record keeping, invented by the world's first sedentary farming communities specifically for this purpose (Schmandt-Besserat 1992a; 1996). It is argued that as people transitioned from an egalitarian, mobile hunter-gathering way of life to living year-round in permanent, hierarchical farming villages, they needed clay 'tokens' in order to count and maintain a record of quantities of livestock, crops and food supplies; and that this need appeared simultaneously across West Asia around 8000 BC (Schmandt-Besserat 1992a, 36, 37, 49, 99; 1996, 7). Like their fourth-first-millennium BC counterparts, clay objects are assumed to have been used as mnemonic tokens in the administration of goods and livestock, with a single, seamless function and meaning stretching from the Neolithic 
into the Early historic period, eventually evolving into and being replaced by the world's earliest known script (Schmandt-Besserat 1992a, 13, 16, 17, 24, 26, 27, 35-48, $49 ; 1996,7,16-17,103)$. Though concerns were raised at the time of publication (such as Pollock 1999, 166; Zimansky 1993), Schmandt-Besserat's work remains mainstream, despite evidence to support her claims, especially the reasons for the initial appearance and use of 'tokens' in the Neolithic period being far from secure.

This article investigates evidence for the predominant interpretation of the earliest 'tokens', those from the Neolithic period. To date no convincing evidence supporting Denise Schmandt-Besserat's interpretation of the function of pre-historic 'tokens' has been published. This paper utilizes new and previously unpublished Neolithic data comprising almost 3000 individually published objects, in addition to data from a total of 79 sites (Table 1). Importantly, the research specifically incorporates information regarding the immediate and wider context of clay objects in the Neolithic. Analysis proves that, far from being the unequivocal precursors of cuneiform script and part of Schmandt-Besserat's proposed symbolic administrative 'token' system, clay objects were basic, multi-functional tools with a range of meanings, functions and uses.

The abundance of clay objects found across an expansive temporal and geographic zone (Fig. 2), spanning the entire West Asian region across many millennia, implies an important role for these artefacts, a role which may relate to one of the many economic, cultural, symbolic and lifestyle changes seen at the start of the Neolithic, the period in which they initially occur. 'Tokens' are characteristic of south Mesopotamia's urban settlements from the late fourth into the first millennium BC. They are commonly recovered in administrative contexts. However, despite the similarity of appearance between Neolithic clay objects and 'tokens' of the fourth millennium $\mathrm{BC}$ onwards, it cannot be assumed on this basis alone that the two performed an identical function, especially when separated by vast swathes of time, space and the differing nature of Neolithic versus early urban communities. 
Furthermore, though common, clay objects are not present at every Neolithic site in West Asia.

Significantly, there does not appear to be a clear correlation between the presence and/or relative number of clay objects according to the nature of the archaeological site (small or large, sedentary village or temporary camp, huntergatherer- or farming-based subsistence, containing evidence of 'elites', hierarchy or social stratification or not). This lack of correlation suggests that, while the appearance of clay objects corresponds to increasing sedentary behaviours, they are not a necessary component of early sedentary agro-pastoral villages as is often assumed (Schmandt-Besserat 1992a, 99, 161, 166-8, 170, 172; 1996, 7, 102). Indeed, their appearance and prevalence in early mixed-subsistence sites, such as at Boncuklu Höyük, requires a full revaluation of the earliest function of these so-called Neolithic 'tokens'. Outside an administrative sphere, clay objects have the potential to have operated within a multitude of different realms: as children's toys, gaming pieces, ritual tools, items of divination, weights, or architectural decorative pieces.

\section{Subject overview}

\section{Neolithic background}

The Neolithic period in West Asia emerged around 12,000 years ago. Exemplified by the appearance of the world's first sedentary agricultural villages, this fundamental change in lifestyle from mobile hunter-gather groups into permanent farming communities was accompanied by many associated long-term changes to the way of life, as humans negotiated new relationships with each other and their environment. The advent of farming and the plethora of associated developments which characterizes the Neolithic undeniably resulted in an irrevocable change in the course of human history (Bender 1978; Binford 1968; Braidwood 1960; Byrd 2005; Cauvin 1994, 2000; Childe 1928; 1936; Clarke 1973; Hayden 1990; Lee \& DeVore 1968; 
Price \& Gebauer 1995; Redman 1977; Verhoeven 2011; Watkins 2010). The corresponding appearance of large numbers of small geometric clay objects at many Neolithic sites in West Asia has long been acknowledged. However, where other small clay artefacts such as sealings and figurines have received much scholarly attention (e.g. Akkermans \& Duistermaat 2004; Garfinkel 1995; Kuijt \& Chesson 2005), geometric-shaped clay objects have been largely overlooked.

It is only the potential of clay objects being used within an advanced administrative system, one linked to the development of the earliest writing in south Mesopotamia (c. mid-late fourth millennium BC), which brought the existence of clay objects to the attention of scholars at all. Despite this, research into the morphology, distribution and use of clay objects has remained limited. Investigation has almost exclusively focused on the proto and Early Historic period of south Mesopotamia, leaving the earliest clay objects, those of the Neolithic, widely ignored (with even the rare, recent publications of clay objects limited to descriptive rather than functional discussions: i.e. Nashli \& Moghimi 2013). This paper offers a complete re-evaluation of the pre-eminent interpretation of the function of Neolithic clay objects. The timing of their appearance and their endurance in West Asia into the first millennium BC suggest that clay objects as tools played an important role in the world's first village societies: perhaps a role which was valued enough to enable the objects to continue being made and used for many generations.

\section{Research context}

\section{Early research}

As early as 1905, J. de Morgan published a catalogue of finds from Elam, including small, geometric-shaped clay objects labelled as 'tokens' and 'counters' (de Morgan et al. 1905). The first systematic study of clay objects, an unpublished thesis, came more than 50 years later (Broman 1958), and the following year a ground-breaking, interpretative article investigating the function of small clay (or stone) objects and 
their association to administrative bullae (hollow clay spheres, often containing 'tokens' and marked on their outer surface with the impressions of 'tokens', cylinder seals and/or writing) was published by Leo Oppenheim (1959). This, along with Amiet's (1966) work, was crucial in linking small geometric clay (and stone) objects to administration and in cementing the link between clay objects, bullae, sealings and early writing in the early historic period in West Asia (Fig. 3).

\section{Schmandt-Besserat}

In recent years, Denise Schmandt-Besserat has been the most prominent scholar in the investigation of small, geometric-shaped clay (and stone) objects. Since the 1970s, she has advanced a detailed set of theories claiming clay objects functioned as accounting and recording 'tokens' and claiming a functional continuity and evolution of complexity from the eighth into the third millennium BC (SchmandtBesserat 1977; 1978a,b; 1979; 1980; 1981; 1982a,b; 1988; 1992a,b; 1996). She argues that the invention of the 'token' system was necessitated by the emergence of nonegalitarian, sedentary agricultural villages c. 8000 BC (before which time people had no requirement to count or keep track of foodstuffs, nor could they conceive of abstract number) (Schmandt-Besserat 1992a, 99, 157-9, 161, 166-8, 170, 172; 1996, 7, 100, 102). 'Tokens', she claims, were symbolic representations, their shape and size standing for a set unit of a specific commodity, in a system which was understood and used across the entirety of West Asia. The system, she claims, became more complex from the fourth millennium $\mathrm{BC}$ onwards due to the increased diversity of produce in circulation at the time (Schmandt-Besserat 1992a, 36, 37, 49; 1996, 16-17). The range and decorative elaboration of 'tokens' increased at this point until the symbols representing 'tokens' became the symbols used to constitute the world's earliest written script c. 4000 years later (Schmandt-Besserat 1992a, 36, 37, 49, 161-2, 198; Schmandt-Besserat 1996, 16-17, 102). 
Schmandt-Besserat argues that an increase in bureaucracy that accompanied the rise of cities and city-states led to new methods of organizing, archiving and storing the 'complex tokens' that had previously been kept together in wooden boxes, cloth bags, baskets or leather pouches (1992a, 97). She claims the hollow clay envelopes or 'bullae' that appear in the early historic period were invented specifically to store clay objects, acting as a permanent archive (Schmandt-Besserat 1992a, 108; 1996, 7). Yet the drawback of this system, as interpreted by SchmandtBesserat, was that the clay objects were hidden from view, and thus began the practice of impressing them onto the outside of bullae while still wet, with identical clay objects to the specimens sealed inside (Schmandt-Besserat 1992a, 108-14; 1996, 7). It was soon realized that the clay objects need not be placed inside the bullae, as their impressions were clear on the outer surface of the envelopes. Therefore the use of clay objects changed, useful now for the two-dimensional markings they made on the surface of wet clay (acting as a stamp), rather than as objects in their own right. Solid clay balls and soon flat clay tablets alone, displaying the impressions of but devoid of actual clay objects, soon became the main method of administration in the Near East (Schmandt-Besserat 1992a, 12-33; 1996, 7). Though this element of Schmandt-Besserat's interpretation relates only to the 'complex', post-4000 BC clay objects, it is noted that the practice of containing clay objects in groups apparently began in the Neolithic.

\section{Questionable elements}

Many elements of Schmandt-Besserat's theory are questionable. Fundamentally, it is now clear that clay objects appeared at the start of the very Neolithic period. They initially appeared at a small number of early agricultural villages in Anatolia, Upper Mesopotamia, the Zagros and the Levant towards the start of the Neolithic period, the mid tenth millennium BC: for example, Sheikh-e Abad, Mureybet, Jericho and Çayönü. By the Late Neolithic (seventh and sixth millennia BC), clay objects are present in abundance at a large number of sites across the region, being particularly 
characteristic of 'Halaf' settlements. However they are not an essential element of Neolithic life, remaining absent at other sites (including Ebaba, Jani, Musular, Pinarbasi, Shir, Wadi Shu'eib, for example: see Supplementary Material (a)) (Bennison-Chapman 2014). Nor do they disappear, being replaced by writing in the third millennium BC. Rather, clay objects continue to be used into the first millennium, commonly recovered in institutional administrative contexts alongside written documents and often sealed inside bullae impressed with cylinder seals (e.g. Amiet 1966; MacGinnis 2013; Woods 2010, 61, 66-8). This is clear and undisputable evidence that clay objects, from the mid fourth millennium BC onwards, performed a function similar, yet not identical, to that of writing

Detailed constructive criticism of Schmandt-Besserat's theories focuses almost exclusively on the latter half of her temporal coverage (c. $4000 \mathrm{BC}$ onwards). At this point, it is clear 'tokens' were part of formal administrative activities. Therefore critical discussion is focused on exactly how clay objects were used in conjunction with bullae, seals and written documentation in the early urban centres of the region in the fourth and third millennia BC. Experts in proto-cuneiform and proto-Elamite writing (the early historic community) were quick to highlight the many flaws in the detail of Schmandt-Besserat's claims (Brown 1996; Damerow 1993; Englund 1993; 1998; Friberg 1994; Michalowski 1993). They have, for example, critiqued the highly simplistic nature of Schmandt-Besserat's interpretation of the evolution of symbols (the supposed symbolic vocabulary of three-dimensional shapes represented by 'tokens' evolving into their two-dimensional impressions on bullae containing the same 'tokens', into markings mimicking two-dimensional 'token' impressions, into early cuneiform script) from the eighth into the third millennium BC (SchmandtBesserat 1992a, 12-33, 108, 109-14, 117, 143-9, 190-94; 1996, 7, 117-22).

They argue that a single, uniform number system could not have existed in West Asia in the Neolithic, nor even before 3000 BC, as the archaic texts of south Mesopotamia and Elam utilized a multitude of numerical notation systems. Each system was context specific, with a range of symbols used to represent specific 
numerical values according to what was being measured or accounted. The same symbol could therefore represent different values when recording wheat and then sheep, for example. The use of abstract number is a concept not evidenced until at least the end of the third millennium BC (around 1000 years after the earliest, archaic texts appear in West Asia), as demonstrated in the abstract sexagesimal place value system (Brown 1996, 39; Damerow 1993, 29-31; 1988; Damerow \& Englund 1987; Englund 1993, 1671; Friberg 1994, 482, 483-4 diagram; Michalowski 1993, 998; Nissen at al. 1993, 125-30, 140, 142-51). Schmandt-Besserat shows a total lack of understanding of this well-known fact of early Near Eastern writing and presents no convincing evidence to support her claim that the earliest cuneiform symbols evolved from and represented the shapes of 'tokens' in two dimensions (Damerow 1993; Englund 1998, 258; Friberg 1994, 482-6). Since her main publications, other scholars specializing in the emergence and development of writing in south Mesopotamia and Elam have expressed similar concerns (i.e. Woods 2014).

\section{Criticism of prehistoric element}

The bulk of Schmandt-Besserat's interpretative discussion and supporting evidence is drawn from the protohistoric and historic-period clay objects, with little direct evidence presented to support her assertion that clay objects were invented by Neolithic villagers, solely for the purpose of administration: no support for the claim that in the Neolithic, the shape and size of 'tokens' formed part of a universal, symbolic code across the region, nor that their function remain consistent across four millennia. Indeed, Schmandt-Besserat's argument is based almost exclusively on data from the fourth and third millennia $\mathrm{BC}$, with interpretations obtained from this applied backwards in time (Schmandt-Besserat 1992a). Despite this, and the criticism of the early historic specialists, Schmandt-Besserat's work has been hugely influential within all branches of archaeology and across secondary disciplines including cognitive archaeology, linguistics and those studying the evolution of numeracy and early mathematics (Bottéro et al. 2000; Coolidge \& Overmann 2012, 
208-9; Coulmas 2003; Fischer 2001; Malafouris 2013, esp. 111-15; Netz 2002;

Overmann 2013, 20; 2015; 2016, 352; Overmann et al. 2011, 143). Her ideas have influenced almost all subsequent studies on the topic and the term 'token' has become synonymous with clay objects and her interpretation of them. Aside from the early historic community, few constructive criticisms of Schmandt-Besserat's theories have been published. Instead, the topic of 'tokens', their presence and function at Neolithic sites and those of later periods is either ignored, or when clay objects are mentioned, merely listed in find inventories, labelled as 'tokens' with reference to Schmandt-Besserat's interpretation - serving only to verify her ideas passively.

Research into the initial appearance and function of the earliest Neolithic clay objects is scarce, yet the identification of the possible origins of symbolic information storage systems and the world's first writing is of huge significance. Thus the focus of this paper is clay objects of the Neolithic. It is clear that, from the fourth millennium BC, clay objects operated within the administration sphere, yet is there evidence for this in the Neolithic? If so, were clay objects used for this purpose at all sites, and in exactly the same way? Only within recent years have excavators began to recognize the potential importance of prehistoric clay objects, incorporating them into site reports and publications (e.g. Çilingiroğlu et al. 2004, 48-9, 125, figs. 31.631.17; Duru \& Umurtak 2005, 109-10, 174, 197, pls. 130, 131, 171), yet corresponding contextual and functional analysis of clay objects is still generally lacking (exceptions include Akkermans \& Duistermaat 1996; Costello 2000; 2002; Jasim \& Oates 1986). Prehistoric clay objects are frequently labelled as 'tokens', with little or no justification of the use of this functional implication, aside from a reference to Schmandt-Besserat's work (e.g. Cole et al. 2013; Eslick \& Voigt 2017, 88-91; Forouzan et al. 2012; Richardson 2014, 44-5). This passive adoption of Schmandt-Besserat's term serves to add support to her theory, yet is presumably more likely due to the lack of an alternative functional interpretation, caused in part by the lack of comparable prehistoric clay objects published in detail. Correspondingly, an 
assumption of the utilization of clay objects within administration is common (i.e. Akkermans \& Duistermaat 1996; Carter 2010, 164; Costello 2000; 2002; Nashli \& Moghimi 2013).

Historic and ethnographic, non-literate counting and accounting systems Looking outside the Neolithic Near East, there are various methods by which sets of identical, similar or dissimilar small objects can potentially be used together to perform simple counts, complex mathematics, record numerical information, or to store more detailed data. In ancient Greece, for example, identical counters were used in conjunction with a flat board marked with lines. The resultant squares were labelled with set numerical values, allowing the 'counters' to be placed as required (Netz 2002). Within this system, complex calculations could be performed, yet the 'counters' themselves retained no numerical value nor symbolic meaning once removed from the board. The method of census record keeping used in the West African Kingdom of Dahomey (c. AD 1600-1900) demonstrates the capacity of similarly small items of inconsequential appearance to retain large quantities of complex numerical and additional information. A simple system utilizing pebbles, baskets, boxes and bags was created in order to collect, amend and retain detailed census information. The number of births, deaths and population counts (according to age and sex by district) were gathered and stored within a system of pebbles. Locational details such as the exact area of the room, box, basket (or compartment of) and colour of the containing receptacle were used to symbolize non-numerical information relating to each person in the census (sex, relative age, living or deceased, manner of death, marital status and district, for example) (Herskovits 1932). In both examples above, the appearance or similarity of the small 'counters' or 'tokens' was not important; merely their small size and portability were their principal properties. 


\section{Alternative information storage systems}

Tallies are widely recognized as the earliest counting aid, which, in addition to calculation, had the capacity to immortalize the information they held. Created by applying notches onto an object or surface, they could be portable, thus transmit information to an infinite audience. Tally use is diverse around the world, valued by a wide variety of peoples and by communities practising a range of subsistence strategies and lifeways: literate and non-literate communities, mobile and sedentary peoples and in both urban and rural settlements, from the Middle Palaeolithic into modern times (d'Errico et al. 2003, 4-6, 31-3, fig. 2; Henshilwood et al. 2009; Jenkinson \& Ellis 2003; Marshack 1991; Robinson 2007, 54; Viteles 1947). Tallies were not necessary replaced by the introduction of writing, nor is their use always restricted to the recording of basic numerical data. Arguably the earliest tally is the Blombos Ochre, thought to be 77,000 years old (Henshilwood et al. 2009, fig. 8, 9, 10; Sy \& Tinker 2006, 110). This and the Ishango Bone (c. 20,000 BP) are just two examples of tallies, widely interpreted as demonstrating an advanced mathematical understanding (Sy \& Tinker 2006, 106, 114, 115). Their understanding directly contradicts Schmandt-Besserat's (1992a, 167) interpretation of pre-Neolithic, huntergather communities as unable to conceive of abstract number, nor having the need to record anything other than lunar cycles. Tallies have been used from the distant past into modern times to record complex administrative transactions and non-numerical information such as 'love conquests' (Viteles 1947, 177). Nor is the use of tallies restricted to non-literate communities (as claimed by Schmandt-Besserat 1992a, 1667). Medieval European tallies, universal in the thirteenth-fourteenth centuries, continued to be used in tandem with parchment and paper receipts in the following centuries (Jenkinson \& Ellis 2003, 66, 68-9).

Knot records (khipu) are a further form of non-literate information storage device. Used by the Andean, pre-Columbian (pre-sixteenth century AD) civilizations native to the area of South America now known as Peru, groups of knotted strings of differing colours, lengths and knot combinations could be 'read' like a text, capable 
of recording all manner of information as expressed in speech (Quilter \& Urton 2002, xvi, 3). Though not fully understood, khipu demonstrates the potential of a seemingly simple item, knotted strings, to record and store all nature of information. From an alternative perspective, marks in the form of symbols and signs have been used around the world, from the Upper Palaeolithic into modern times, in literate and non-literate societies, to indicate a multitude of information, ownership, identity, in all manner of contexts (e.g. on livestock, artwork, buildings, open spaces and territories) (Pim et al. 2010).

\section{Aims and methodology}

\section{Aims}

This project offers a total re-evaluation of previous evidence in relation to Neolithic clay objects in order to address the unanswered questions regarding their initial emergence and use in the Neolithic, namely their form, function and distribution. It re-evaluates the validity of Schmandt-Besserat's theory alongside alternative interpretations. Schmandt-Besserat (1992a,b; 1996) argues that clay objects are 'tokens', invented specifically by Neolithic villagers to count, and later in the Neolithic period and beyond for long-term information storage in the administration of agricultural produce and other commodities including finished good. Data collection was carried out in three broad categories focusing on a) the individual objects, b) the immediate context of each object within a site and c) general site characteristics.

Entire assemblages of clay objects from a number of different sites were studied in order to establish the degree of similarity of objects within, and across, different assemblages, identifying groups potentially capable of being used to convey the same symbolic meaning. In order to achieve this goal, intensive recording of the morphology of clay objects (including shape, size and weight) as well as manufacturing methods and materials, wear, and state of preservation was carried 
out. Alongside morphological study, the immediate find contexts of clay objects and the nature of sites with and without the presence of clay objects were compared, in order to see whether or not there is any correlation in the nature of a site and the range of on-site activities and the presence of assemblages of clay objects.

\section{Definitions}

The term 'clay object' is used in this paper to describe the small, geometric-shaped clay artefacts most commonly described as 'tokens', also referred to in archaeological literature as 'counters', 'jetons', 'gaming pieces', 'cones', 'figurines' and the like. This study defines clay objects as small artefacts (generally $<5.00 \mathrm{~cm}$ ), intentionally crafted into a clear geometric form (i.e. cone, sphere, disc, cube). They may be plain, or display impressions or intentional decorative markings (Fig. 4). Signs of intentionality include finger and nail impressions, finger-tip indentations and a certain level of finish to the objects. Items of all types of clay, burnt or unburnt, complete or incomplete, can be included. However, enough of the original object must be present in order to be sure the object in question was a small, geometric object, and not a fragment of a larger object (the tail or leg of a zoomorphic figurine, for example). Comparable objects of plaster and stone are included, yet for the purposes of this study, artefacts made from re-used pottery sherds (discs or 'jetons', i.e. Costello 2000; 2002) are excluded. The placing of artefacts into typological categories is problematic as all are, to some degree, subject to human interpretation and not all artefacts neatly fit into a single category; therefore all objects considered as 'clay objects' in this study were individually considered against project-specific criteria above, disregarding on-site or published classifications and terminology.

\section{Object recording}

At total of 79 Neolithic sites form the basis of this research. According to the detail of evidence (full, individual artefact descriptions versus basic, and general description of an artefact group) and completeness of data sets available (access to all versus only 
a fraction of clay objects from any given sites along with the availability of contextual information), and in order to facilitate like-for-like comparison, sites included in this study were grouped into three 'tiers' of information: tier 1, direct observation case-study sites ( 3 sites); tier 2, museum collections and publications (20 sites); tier 3, general descriptions in literature (56 sites) (Table 1; Fig. 2). The tier 1 and 2 data combined incorporate details of 2918 individual clay objects, covering 23 Neolithic sites, spanning the temporal and geographic extent of Neolithic West Asia (Table 1 \& Fig. 2).

Just over half of all objects individually recorded come from the three casestudy sites of Boncuklu Höyük (672 objects) and Çatalhöyük East (676 objects), both on the central Anatolian Konya plain, and Tell Sabi Abyad (393 objects) in north Syria (see Fig. 2 for locations). These case-study sites comprise the tier 1 sites and were selected due to their large assemblages and well-documented excavation contexts. At each, access to all excavated materials and artefacts of clay was available, potentially allowing all excavated artefacts fulfilling the criteria of clay object to be studied and recorded in detail, in person. In addition to object morphology and manufacture, information related to specific, individual find context, broader context and artefact associations was available for each and every single tier 1 object studied. At Çatalhöyük and Boncuklu Höyük, all excavated clay objects to date were individually recorded. The Tell Sabi Abyad records comprise a representative sample of objects recorded in person in 2008 in addition to the study (from detailed unpublished excavation records) of a further sample of objects from a range of occupation areas and periods.

Context is key in assessing object function, though it must be noted that the find spot often represents the disposal location, not necessarily the location of object use. All context records, no matter how detailed, can be subjective; therefore where available for tier 1 sites, rather than merely noting the 'type' of context a unit was classified as (midden, burial, pit and so on), full context descriptions were studied. This was undertaken at all context levels, primary, secondary and tertiary categories. 
This approach enabled an understanding of how and why particular context types were assigned. Evidence of the containment of groups of clay objects was particularly sought. It is clear that, from the fourth millennium $\mathrm{BC}$, clay objects were used, stored and retained together inside bullae; therefore evidence for the precursors to such a system (the containment of groups of clay objects in pouches, baskets, boxes made of organic materials, ceramic or stone) was sought. The nature of the context of all in situ clay objects was examined to see if any other artefacts were placed in direct association, forming clusters of artefacts which may have been used together, and perhaps stored as a group in any type of vessel. The remaining individually studied objects come from sites where a limited proportion of clay objects was available for study. These have been defined as tier 2 sites and the data were drawn mostly from published material, but included some collections viewed at first hand. All had very limited contextual detail (Table 1 \& Supplementary Material (b) \& (c)).

\section{Broader object survey}

To complement the data gathered, broader trends in the distribution of clay objects within Neolithic West Asia were considered by the incorporation of data from an additional 55 (tier 3) sites (Fig. 2 \& Table 1). Covering the entire Neolithic period and all regions within West Asia, the main aim was to chart the presence or absence of clay objects across the region during the Neolithic, comparing a multitude of site characteristics to the presence, relative number or apparent absence of clay objects, attempting to equate this to environmental, temporal and/or human-made factors such as the size and nature of the settlement at which they are found or from which they are apparently absent (see Supplementary Material (a)). This broader approach was employed in an attempt to link the new presence of clay objects within Neolithic settlements of West Asia to the many new behaviours and lifestyles appearing at the time. 


\section{Evidence}

\section{Boncuklu Höyük: case-study 1}

Boncuklu Höyük (Fig. 2) is a small, 1 ha aceramic Neolithic settlement which was occupied for around 1000 years, from the mid ninth to the mid eighth millennium BC (Baird forthcoming; Baird et al. 2012, 221). The site, currently under excavation by Prof. Douglas Baird of the University of Liverpool, UK, demonstrates a community of cultivators, farming both wild and domestic plants and exploiting a wide range of hunted species (Baird 2002; 2006; 2007; 2009; 2010; 2012a,b; forthcoming; Baird et al. $2011 ; 2012,228-30)$. Small, geometric clay objects are the most abundant find classification at Boncuklu. The site's clay object assemblage incorporates a wide variety of three-dimensional shapes (Fig. 5). Within each shape category, a low level of standardization across other visual characteristics is seen. Yet generally, the assemblage is homogenous in terms of the overall range of object forms and manufacture technique, for example. Spheres are the most common 'basic' shape (39.18 per cent), followed by discs (31.13 per cent) (Fig. 5). In total, 14 'detailed' three-dimensional shapes (including sub-types) are represented (see Fig. 1.b, d, e \& Fig. 6). Three quarters of Boncuklu's clay objects weigh between 0.30 and $3.99 \mathrm{~g}$ with an average of $3.38 \mathrm{~g}$ and 15 per cent of clay objects display intentional 'markings'. Three objects within Boncuklu's clay object assemblage are remarkable, each exhibiting a pair of parallel, deeply incised, straight lines on the upper, convex surface. All three (CO\#s 1508, 871 and 1465) are also comparable in size, shape and clay colour (Fig. 7), yet contextually each comes from a separate area and settlement phase. At both Çatalhöyük and Boncuklu Höyük, 'middens', representing refuge disposal accumulations including sweepings from inside buildings, are the context type which yields the largest number of clay objects (41.65 per cent and 47.58 per cent, respectively), showing that clay objects were commonly disposed of. However, density analysis at Boncuklu Höyük proves that, proportionately, clay objects are most commonly recovered from building 'floor surface' contexts, presumably 
representing the location of primary use. Boncuklu's three most common shapes (spheres, ovoids and discs) co-occur in almost every building where clay objects are found (Bennison-Chapman 2014, fig. 6.14). None of the clay objects from Boncuklu was recovered in direct association with another clay object (or other artefact type), thus no direct evidence for them having been used, stored or disposed of in a group (as later evidenced by their containment inside bullae) was found.

\section{Çatalhöyük: case-study 2}

Renowned for its large size, density of settlement, excellent preservation and abundance of symbolic material culture; Çatalhöyük (Fig. 2) has been the subject of international archaeological research since the 1960s (Hodder 1995; 1996a,b; 1997; 1998; 1999a,b; 2000; 2001, 2002; 2004; 2005a,b,c,d,e; 2006a,b; 2010; 2013a,b; 2014a,b; Mellaart 1962; 1963; 1964a,b; 1965a,b; 1966; 1967; 1975; 1978; Tringham \& Stevanovic 2012). Çatalhöyük lies in close proximity to a number of contemporary sites in the Konya Plain including Boncuklu Höyük, Pınarbaşı and Can Hasan (Hodder et al. 2006, 4, fig. 1.1). Çatalhöyük's main 'East Mound' has been the central focus of research, evidencing more than 10 levels of continuous occupation c. 7400-6200 BC, spanning the Levantine Late Pre-Pottery Neolithic B into the Ceramic Neolithic period (Cessford 2005, 77, fig. 4.3; Hodder et al. 2006, 20-21). Thus Çatalhöyük's earliest levels are contemporary with the latest phases at neighbouring Boncuklu Höyük (Baird et al. 2012: 221, 232) and many features characteristic of Çatalhöyük manifest themselves at the earlier site. Çatalhöyük's clay objects, rather than forming one clearly identifiable artefact category -'tokens' - more likely resemble a fraction of a number of divergent artefact assemblages, united by similar manufacture and visual characteristics, yet composed of multiple assemblages of clearly distinct types. A broad range of three-dimensional shapes is represented, yet spheres and flatbased discs are by far the most common (see Fig. 1.a, c, f \& Fig. 5). Shape definition and object size standardization within shape categories is more apparent here than at Boncuklu Höyük, and within certain shape categories a smaller number of highly 
uniform object sets can be found (Bennison-Chapman 2013, fig. 15.15). Cone 'set B', for example, are seven cones, each with a round base in plan view. Their tips are pointed and the ratio of height to base diameter regular. Each is crafted from the same smooth, marly-grey clay, with a 'very smooth' surface finish and a flared base. Each is 100 per cent complete, though in dimensions and weight the objects vary (0.6-3.2 g, 1.0-1.4 cm in height) (CO\#s 117-1120, 1080, 1151 and 1084: Fig. 8).

However, such uniform sets always come from disparate contexts, with no likelihood they were used together as a group. As at Boncuklu Höyük, no evidence for the storage and retention of groups of clay objects inside containers was recovered, despite the common survival of basketry, wooden containers and fabric pouches (e.g. Doyle 2017, 204; Jørgensen \& Rast-Eicher 2017; Lingle \& Seifert 2017, 264; Mellaart 1967, 105-8, 116-18). In situ depositions of clay objects are rare at Çatalhöyük, with just nine (1 per cent) of studied clay objects being recovered from a 'cluster' context (defined as the in situ deposition of at least one clay object, alongside additional artefacts of any form). The presence of caches of large numbers of small, unfired spheres, recovered exclusively together in pits or basins, sealed with plaster under building floors (F. 758, which contained n=727 'mini clay balls' inside, for example: see Atalay 2012, 14/5-6) are rare yet notable, suggesting a special function for at least some of Çatalhöyük's spherical clay objects. Aside from these few examples, artefact clusters incorporating clay objects at Çatalhöyük are extremely rare, and contain between one to three clay objects in addition to items such as ground stone artefacts and animal bones (Bennison-Chapman 2014, table 7.11). No examples hint at the presence of portable containers to be carried, passed from person to person, or used to hold clay objects as a permanent archive of a transaction, as has been suggested for the Neolithic period (Schmandt-Besserat 1992a, 97) and later seen in the use of bullae from the fourth millennium BC onwards. 
Tell Sabi Abyad: case-study 3

Tell Sabi Abyad (Fig. 2) was excavated by Prof. Peter Akkermans, University of Leiden in the Netherlands, from 1985 until 2010 (Akkermans 1989; 1993; 1996a,b; Akkermans \& Duistermaat 1996; 2004; Akkermans \& Verhoeven 1995; Akkermans et al. 2010; 2012; Duistermaat 1996; Duistermaat \& Schneider 1998; Verhoeven 1999; 2000; Verhoeven \& Akkermans 2000). The site is comprised of four prehistoric tells, varying in size from 0.5 to 5 ha (Akkermans et al 2014, fig. 1.9; Nieuwenhuyse et al. 2010, fig. 3). Neolithic occupation at Tell Sabi Abyad spans more than one-and-a-half millennia from the late eighth into the first half of the sixth millennium $\mathrm{BC}$, the late Pre-Pottery Neolithic into the Middle Halaf periods (Akkermans et al. 2014, table 1.3; Nieuwenhuyse et al. 2010, fig. 5; Verhoeven \& Akkermans 2000, 1-2). Despite its size, Tell Sabi Abyad was never simultaneously occupied. Settlement shifted from tell to tell and eastward across the largest mound Akkermans et al. 2014, 32, fig. 1.8; Akkermans et al. 2010).

Of the 393 clay objects studied from Tell Sabi Abyad, most appear to have been produced in a far more standardized fashion than at the other case-study sites. The objects are finished to a high standard, and within each shape category a greater level of shape definition is evidenced. This is further enhanced by the presence of a number of homogenous sub-sets of clay objects within the already uniform shape categories, with a greater level of consistency across the many variables than seen at Çatalhöyük and Boncuklu Höyük. In addition, at Tell Sabi Abyad, many of the objects within the generally diverse 'other' category can be grouped into subclassifications (vessels, flat triangles and so forth). Though related to excavation techniques and data collection to a degree, this patterning remains true even taking all factors into account.

The proportion of 'marked' or decorated objects varies significantly at Tell Sabi Abyad, according to object shape. Discs, cones, flattened/semi-spheres and flattened/semi-ovoids, for example, all display high proportions of marked objects. Similarly, fingerprints are rare on objects of certain shapes, while far more common 
on other-shaped clay objects (i.e. 2.86 per cent of spheres compared to 14.81 per cent of type-4 cones). Along with discrete sets of similar objects, Tell Sabi Abyad's clay object assemblage also includes a small number of unique, highly crafted objects including a disc stamped with a round stamp-seal impression on both sides (CO\# 105: Fig. 9), an incised cylinder (CO\# 2911: Verhoeven \& Akkermans 2000, fig. 4.7.3), a stone cone-shaped object (CO\# 2879: Akkermans 1996b, fig. 8.5.5) and a similarly shaped, truncated cone, incised on the front surface with at least 10 deep holes (CO\# 226: Fig. 10). Differential patterning is also apparent in the contextual distribution of Tell Sabi Abyad's clay objects. Those recovered from 'external' open-air contexts tend to be recovered as lone, single objects. Clay objects recovered from 'internal spaces' tend to come from two extremes, either rooms containing only one or two clay objects and few other artefacts, or from rooms full of up to 100 or more clay objects and similar artefact types (Akkermans \& Verhoeven 1995, 13, 15, 24; Akkermans et al. 2006, 129, 131-32; 2012, table 2; Bennison-Chapman 2014, tables $8.21,8.23 \& 8.25)$. It is tempting to interpret the latter as evidence that clay objects were used together. This may be the case, yet these rooms do not represent administrative archives.

The overwhelming majority of Tell Sabi Abyad's' internal space clay objects are recovered from artefact caches within room fill (71.57 per cent of 'internal space' objects come from clay object 'clusters'). These consist of other clay objects, alongside similar objects including clay figurines, sealings and jar stoppers (Akkermans \& Duistermaat 1996, 19; Akkermans et al. 2012: fig. 7, table 2; Akkermans \& Verhoeven $1995,8,13,15,24)$. Once interpreted as in situ depositions indicating the existence of organized storage in the form of archives at level 6, Tell Sabi Abyad I (Akkermans \& Duistermaat 1996; Akkermans \& Verhoeven 1995, 15), it is more likely that, as the excavators now agree, these rooms full of artefacts most likely represent the in-filling with refuse of rooms within abandoned buildings, as mirrored in the burnt building at Sabi Abyad I, operation II (Akkermans et al. 2012, 317-18). Therefore, whilst the mass, group disposal of large numbers of clay objects, sealings, figurines and the like 
points to the use of such objects together, an important distinction (at operation I level 6 and operation II only), once their role was complete, clay objects were thrown away, not stored together in containers as part of archives. Thus, as at Boncuklu Höyük and Çatalhöyük, the largest proportion of clay objects at Tell Sabi Abyad come from refuse contexts representing disposal, not primary-use locations.

Though level 6, operation I at Tell Sabi Abyad has no evidence for the containment of clay objects, the large number of sealings, again recovered from the in-fill material of specific rooms of mainly rectilinear buildings (Akkermans \& Duistermaat 1996, fig. 1), shows that the residents were storing belongings (agriculture or otherwise) in a secure fashion, marking the ownership of the containers (varied: see Duistermaat \& Akkermans 1996, table 1) by the impression of unique stamp seals (Duistermaat 1996, 372-3). It is unlikely clay objects were stored, as the number of broken sealings recovered (201 in Room 6 Building III, 36 in Room 7 Building $\mathrm{V}$, for example) far outnumbers the quantities of clay objects (40 and 7 in the same locations, respectively) (Akkermans \& Duistermaat 1996, fig. 1; BennisonChapman 2014, table 8.23). Yet the co-occurrence of the largest quantities of clay sealings and clay objects in the same rooms shows a clear connection between the two within operation I's level 6 village (c. 6010-5995 cal. BC: Akkermans et al. 2014, tables 1.2 \&1.3). Evidence from operation II at Tell Sabi Abyad I shows similar patterning (Akkermans pers. comm. Oct 2016; Akkermans et al. 2012).

\section{Other sites}

Like Tell Sabi Abyad, the 163 studied objects from 'Ain Ghazal (Fig. 11; Rollefson et al. 1992) are characterized by a high level of craft, clearly defined shape and diversity in a variety of visual and manufactural aspects. Stone (various types) as well as clay objects are present in a range of contrasting colours (Fig. 11). Intentional markings are relatively common (10.18 per cent), present on objects of both clay and stone, and 11 detailed shape categories are represented (Supplementary Material (c)). The sheer diversity seen in many aspects of the presence, distribution and range of clay objects 
in circulation during the Neolithic in West Asia is illustrated by the close examination of additional clay object assemblages' from 20 'tier 2' sites (Table 1). Covering 1158 objects, diversity characterizes the tier 2 assemblage in all aspects of object craft and appearance, with a lack of correlation between the presence, number, range and uniformity of clay objects across sites, even those within the same region and time period (Supplementary Material (b)). The broader (tier 3) survey of clay object presence/absence across the Neolithic of West Asia demonstrates that clay objects are found across the entire region from the onset of the Neolithic, at (but not limited to) Demirköy, Mureybet, Körtik Tepe, Hallan Çemi, Tell ‘Abr 3, Jani, Munhata, Qermez Dere and Göbekli Tepe (Supplementary Material (a)). Few regional or temporal distinctions are evident. The use of 'token' technology does not show a gradual increase during the occupation of a single site, nor temporally within a given region during the course of the Neolithic. The exception is the Late Neolithic of the sixth millennium BC, in the Halaf 'cultural' zone of upper Mesopotamia, where similarity in the context and form of objects across some sites including Tell Halaf, Tell Arpachiyah and Tell Sabi Abyad is attested (Bennison-Chapman 2014, chapter 9). Notably, clay objects are often found almost exclusively within only a single level or phase of occupation at some sites (e.g. Middle PPNB 'Ain Ghazal, Çayönü's 'Cell' Phase, Phase D at Hajji Firuz Tepe and the Sanctuaries Phase at Höyücek), evidence against their function as administrative tools necessitated by the presence of agriculture (see Supplementary Material (b)). Likewise, clay objects are recovered from a variety of context types. Midden contexts form the location of the majority of clay objects at Çatalhöyük and Boncuklu Höyük. The same is true of Tell Sabi Abyad, except for level 6 of operation I and operation II, where almost all clay objects were recovered from buildings. Almost all of Çayönü's clay objects come from a single building, interpreted as residential (Çambel \& Braidwood 1979, 149, lower fig. b; Hole 2000, 200). Though found in all phases, the majority of clay objects of sixth-millennium Hajji Firuz Tepe (all cones) were recovered together, on the floor of structure VI, in association with Burial 3 (c. 5812 cal. BC: Voigt 1983, 548-49); while 
at Es-Sifiya, 100 per cent of recovered clay objects come from a single building, a 'workshop' (Mahasneh \& Gebel 1998). Höyücek's Sanctuaries Phase is characterized by the building of open-air religious structures on virgin soil and an apparent lack of domestic dwellings (Duru \& Umurtak 2005, 164-7, 173-6, 225, 243). The structures contained large numbers of finds, including geometric clay objects of various shapes. These are present in one structure only, intentionally placed, in a deliberate act and symbolic location within this distinctive phase of settlement, in which Höyücek acted as a pilgrimage site, a religious cult centre (Duru \& Umurtak 2005, 174-7). At 'Ain Ghazal, none of the objects are recorded as being recovered in conjunction with other clay objects or artefacts. They come from a range of context types, the largest proportion being 'ashy fill' areas (Iceland 2010a, b). The contextual evidence suggests differing disposal practices, location of primary use and therefore differing functions of clay objects across the sites at which they are found.

\section{Discussion}

Extensive analysis of large assemblages of clay objects from 79 sites across Neolithic West Asia proves many previously held assumptions regarding the distribution, form and meaning of small, geometric clay objects in the Neolithic of West Asia to be incorrect. Clay objects appear at the start of the Neolithic period, two millennia earlier than previously recognized (Supplementary Material (a)), and in opposition to the commonly held assumption are not a necessary component of Neolithic agropastoral villages. This research highlights the considerable diversity in all spheres of evidence related to geometric clay objects in the Neolithic, including their presence or apparent absence and the type of sites they appear at, as well as perceived levels of object and assemblage homogeneity (Supplementary Material $(\mathrm{a}-\mathrm{c})$ ). Diversity is also evidenced in the immediate contexts in which clay objects are found (e.g. refuse contexts, domestic, administrative and possible ritual contexts), pointing against a singular and universal functional role. 
Significantly, the broader analysis incorporating all 70 tier 2 and 3 studied sites shows that clay objects were not universal across Neolithic farming villages and therefore cannot have been an essential tool of sedentary farming societies of the time (in opposition to Schmandt-Besserat e.g. 1992a, 161, 166-8, 170, 172; 1996, 102). Equally, clay objects are not absent from all but fully agricultural, large, complex farming villages. Crucially, they also appear at villages where hunting and/or gathering (as opposed to agriculture) is the main subsistence strategy, i.e. Boncuklu Höyük. These findings have profound implications for the interpretation of the use of clay objects and accordingly the nature of Neolithic village societies. SchmandtBesserat's theories have influenced our view of the nature of Neolithic society, yet there is no evidence that all Neolithic villages were based on agriculture, nor is there evidence that all such communities placed importance on keeping a tight record of foodstuffs, livestock and goods, which in turn would have required a high level of social organization and control.

Boncuklu Höyük was occupied for up to 1000 years, yet there is no evidence for an evolution in clay object use throughout this time, despite, as at Çatalhöyük, 100 per cent of excavated objects being studied. The dominance of the three most common shapes (spheres, ovoids and discs) changes little across different context types or temporal phases. The study of specific buildings containing clay objects shows that all buildings at Boncuklu contain at least one clay object, though this is not to say that each and every Boncuklu resident used the objects, nor that every household contained an object at all times, as the buildings were not all simultaneously occupied. Interestingly, buildings that contain 10 or more clay objects display near-identical groups; that is, in three-dimensional shape they are dominated by a combination of spheres, ovoids and discs, which combined comprise around three-quarters of 'house' assemblages. The same three shapes dominate midden assemblages. This suggests that these three main shapes functioned together as sets of objects, with shape being the distinguishing feature. At Boncuklu Höyük, 
clay objects of other shapes may have been utilized within a different functional realm entirely, a realm which is inconclusive at present.

Çatalhöyük's clay objects, rather than forming one clearly identifiable artefact category - 'tokens' - more likely resemble a fraction of a number of divergent artefact assemblages, united by similar manufacture and visual characteristics yet comprised of multiple assemblages of clearly distinct types. Again, 100 per cent of Çatalhöyük's excavated clay objects have been studied and, as at neighbouring Boncuklu, clay objects at Çatalhöyük also appear to be tied to domestic use, evidenced by their context within both houses and middens (representing the refuse from domestic spaces and other household-based activities). The few in situ clusters of artefacts including clay objects all come from domestic spaces. As with Boncuklu Höyük, the overall large number of clay objects recovered from Çatalhöyük suggests they have the potential to have been utilized by the majority of households. As they are crafted from clay (an abundant, locally sourced, ubiquitous raw material) and were easily manufactured, intrinsic value was not within the objects themselves, but in the meaning imbued to them upon production and use. The same is true for the other case-study sites. It seems inappropriate to attempt to assign Çatalhöyük's entire clay object assemblage to a single functional category. The plain, schematic and varied nature of much of Çatalhöyük's assemblage would suggest the objects were multi-functional. The same or a similar set of clay objects may have been utilized by different people or groups of people in different ways. Within the domestic sphere, some clay objects could have been used in simple counting or accounting. Yet their presence was not a necessary element of daily life, and clay objects were not systematically archived as a record of economic activity. If used in simple counting, clay objects may have been used to count all manner of things, not limited to foodstuffs. It is equally plausible that clay objects were used within the home as gaming pieces. Though no gaming boards have been recovered from either site, they would not necessarily survive in the archaeological record, depending on 
material, and examples of contemporary gaming boards are known (Bartl et al. 2011, fig. 28; Simmons \& Najjar 2006, fig 7; Simpson 2007, 5-7).

Tell Sabi Abyad is the only case-study site with convincing evidence for the use of clay objects in the accounting sphere. Yet even at this site not all clay objects can be assigned to this role. Tell Sabi Abyad demonstrates clear and indisputable evidence of the widespread utilization of clay objects in counting activities within certain discrete temporal and locational phases. Operation I's level 6 and both phases of operation II contain huge quantities of clay objects in contrast to other areas and temporal phases of occupation. This, in conjunction with the distinct contextual distribution of clay objects in these two areas compared to all other areas and phases of occupation at Tell Sabi Abyad (all areas and phases have been studied, despite only a sample of clay objects from Tell Sabi Abyad being recorded at tier 1 level), shows distinct similarities. Thus, despite its long occupation span $(>1000$ years), clay objects were not essential components of agricultural village life for most periods of Tell Sabi Abyad's existence. The form, range of shapes and contextual deposition of the clay objects in operation I level 6 and operation II suggest they likely acted as tools utilized in basic counting or accounting activities. Yet this evidence is temporally and geographically limited, with no evidence to suggest the role was evolutionary, nor consistent across different phases of occupation and areas of settlement.

\section{Conclusions}

This study has shown that geometric clay objects appear earlier than previously recognized, yet they are not a necessary component of Neolithic agro-pastoral villages, being definitively absent at some. In the Neolithic, there is no evidence to suggest so-called 'tokens' were used exclusively to administer agriculture produce, and that their role within a supposed system of resource management was identical at each site within West Asia, nor for the duration of the Neolithic. In opposition to 
the dominant hypothesis (Schmandt-Besserat 1992a; 1996), there is no evidence for the spread of 'token' technology or the adoption of a 'token' system of agricultural administration, either temporally or geographically, within the Neolithic of West Asia. No set 'token' assemblage exists within any single site, let alone across contemporary sites, even within a small geographic region. No correlation is evidenced between the range and specific type of goods and foodstuffs in circulation at any given site and the shape and/or range of 'tokens'. Thus it is highly unlikely that a set repertoire of 'tokens', each standing for a specific commodity within the Neolithic of West Asia, was in operation. Sites reliant on the same animal or plant foodstuffs do not demonstrate the dominance of a particular 'token' shape. Likewise, temporal changes in the dominant subsistence strategy within a given site are not accompanied by corresponding changes in the dominance of clay objects from one three-dimensional shape to another.

At most sites studied, sets of objects, identical in all aspects including detailed three-dimensional shape, colour, size and level of craft, are absent. If clay objects were used as a 'code' in the way Schmandt-Besserat suggests, a high level of artefact definition and homogeneity would need to be present within and across sites, if, for example, a cone at Boncuklu Höyük had the same meaning and value as a cone at 'Ain Ghazal. Certainly at the case-study sites identical objects are largely absent, and when groups of objects displaying remarkable similarity (of shape, size, finish, colour), they relate to different levels of settlement, meaning they cannot have operated together as a group representing a specific number of a set item. A limited number of sites do exhibit sets of identical geometric objects, Çayönü's 33 stone 'pawn'-shaped objects and Tell Kurdu's identical clay cones being notable exceptions (Çambel \& Braidwood 1979, 149, lower illustration b; Özbal et al. 2004, fig. 13.15-18). In the case of Çayönü specifically, all 33 examples were recovered together from a single phase of a building, evidence suggesting the objects were used together. Yet the lack of sets of identical objects of additional shapes excludes 
these objects from being part of the symbolic system of administrative 'tokens' that Schmandt-Besserat proposes.

Similarly inconsistent is the lack of correlation between the types of sites at which clay objects appear. Rather than being universal at sedentary farming villages, they are found in large quantities at sites displaying varied characteristics: small and large sites, permanent sedentary settlements and smaller sites interpreted as temporary camps or seasonal ritual sites, sites in all environmental zones. The lack of homogeneity in terms of distribution surely is evidence in support of a lack of a uniform function within a single time period, region or site within Neolithic West Asia. Variability is also evidenced in the immediate contexts in which clay objects are found (e.g. refuse contexts, domestic contexts, administrative contexts, possible ritual contexts), across and sometimes within sites (i.e. Tell Sabi Abyad, Çayönü, Boncuklu Höyük and Çatalhöyük and Es-Sifiya). This diversity across and within sites suggests that clay objects fulfilled a multitude of functions: thus the so-called Neolithic 'token' is somewhat of a myth.

The most likely primary function for clay objects is their use in simple counting tasks. They may have involved the counting of all manner of things: supplies of agricultural goods, but also times (days from planting until harvest, lunar cycles, days from the departure of an expedition), people (the number of people who left on the said expedition) and the like. In such a system, the visual characteristics of the clay objects would be unimportant, with one object representing one unit of time, unit of a commodity or a single item (single animal, piece of fruit, vegetable and so on). At sites such as Boncuklu Höyük where clay object size is not standardized, nor shape well defined and consistent within three-dimensional shape categories, such a simple system of basic, one-to-one counting is highly plausible. At Çatalhöyük, too, the bulk of clay objects at the site likely served this purpose. Piles of clay objects may have been retained, either on the body, or in a simple pile in the corner of a room, for example. They would be disposed of once they were no longer needed, once a group of counted travellers had returned (disposed of as a group), or one by one 
corresponding to the loss of an animal, member of the community or use of a set of grain, for example. However, at Çatalhöyük especially, this scenario does not explain why villagers would not simply make the easiest shape-spheres-and would take the time, in some instances to craft well-made cones, lozenge-shaped objects, or cuboids, for example. Present in low proportions, such shapes perhaps fulfilled different functions to the mainstream; thus though still classified as a 'clay object' by the modern archaeologist, to Neolithic people they had a different meaning altogether. Alternative functions include gaming pieces (a role suited to the shape of the tall, pointed cones of Çatalhöyük especially) and the use of clay objects as 'lots': groups of items thrown or selected from a container, the resultant positioning of the items, the shape or style of the single one representative of a particular decision to be taken, act to be performed or person to be selected for a specific task. In this context, the rarer, more distinctive clay (and stone) objects from Çatalhöyük and Tell Sabi Abyad have a role where their distinctiveness in addition to their uniqueness is necessary and valued.

Tell Sabi Abyad is unique amongst the case-study sites as having distinctly disparate patterning in terms of both the quantity and contextual deposition of clay objects temporally, according to neighbourhood or village ('operation'). Clay objects were clearly used along with sealings, being disposed of simultaneously, given the equally large proportions of both artefact types within specific rooms of certain buildings in operation II and level 6 of operation I. The presence of sealings indicates stored items, yet at the level 6 'Burnt Village' at least, the number of sealings vastly outnumbers the quantity of 'tokens'. The sealings are all unique in design and are broken (indicating the container or package they once contained has been opened). Sealings cannot be re-used. 'Tokens', however, can be used again and again with no damage. In a system where clay objects are neither retained nor achieved, clay objects were likely used to count out the number of stored or retrieved (sealed) containers, or the goods stored within the containers upon sealing or re-opening, thus explaining the disproportionately low number of 'tokens' as opposed to 
sealings. The shape of the clay objects recovered from operation I's burnt village is restricted, thus meaning may have been assigned according to shape-on an ad hoc, transaction-by-transaction basis within a simple system of counting (shape varying according to ownership or identity of receiver, quantity of the same item or representing specific and individual items).

Yet still, at Tell Sabi Abyad, clay objects were multi-functional tools. The low proportion of clay objects outside the two operations mentioned above suggests their use in counting activities was not widespread for most of the site's occupation. The presence of a small number of unique and highly crafted examples of small geometric objects in clay and stone, from diverse levels and areas of settlements, supports the interpretation of a different and unique function of these items. Indeed, the notches on the stone cylinder CO\# 2911 (Verhoeven \& Akkermans 2000, 108 \& fig. 4.7.3) suggest its use as a tally, while a stone cone with similar notches might have performed the same role at 'Ain Ghazal (CO\# 1700, 'Ain Ghazal find no. 4273.000, unpublished). In this regard, not all small, geometric clay (and stone) objects performed the same primary function; they were multi-functional tools. The most common primary function was in the counting of a multitude of things, not limited to agricultural produce, but likely covering periods of time, as well as people. They did not retain any intrinsic value or symbolism; any meaning assigned to them was on a local and temporary basis. As such, clay objects were not archived, and once their use was complete, they were readily disposed of in middens, or in the fill of abandoned buildings (in the case of Tell Sabi Abyad operation I and II).

These findings have profound implications, not only for the interpretation of the use of clay objects and accordingly the nature of Neolithic village societies; the assumed function of Neolithic clay object as 'tokens' has directly impacted on the wider understanding of humankind in a broader sense: our cognitive abilities, the evolution of the ability to understand and convey abstract numbers, the ability to perform counting tasks, the use of inanimate objects as symbolic information storage devices. The understanding of all such developments is incorrectly based on the 
apparent sudden, and universal, appearance of clay 'tokens' acting as mnemonic recording devices in the early Neolithic period (Malafouris 2010, 8; 2013, 106-11, 111-15; Netz 2002; Overmann et al. 2011, 143; Schmandt-Besserat 1992a; 1996, 7, 100, 102; 1996, 6-7). There is no evidence for a Neolithic, Near East-wide, universal accounting system. Thus it certainly cannot be claimed that such a system persisted for millennia, eventually evolving into the earliest symbols of writing (SchmandtBesserat 1992a; 1996). The claim that 'tokens' were replaced by writing and fell out of use in the third millennium $\mathrm{BC}$ is also unjustified. To the contrary, clay objects are common at many second- and first-millennium BC Mesopotamian sites, often used alongside writing. The enduring existence of clay objects for up to 3000 years after the advent of writing clearly demonstrates that their exact functional role during this period also needs re-assessing. Though clay objects played a crucial role in administration in these later periods, the role was likely distinct from that served by written records.

Their generally large numbers when present, variability of deposition, high proportion found in disposal contexts, their simple shape and often crude appearance proves 'tokens' were quickly and easily made and disposed of as readily. Though at times, at a small number of sites, within certain phases of a settlement, clay objects may have been used as tokens by certain groups of people in counting and/or record keeping associated with agricultural production, at Neolithic Tell Sabi Abyad for example, other roles are also likely for some clay objects. It is not until the latest phases of the Neolithic that any solid evidence for the use of geometric clay objects in the accounting realm materializes, as evidenced at Sabi Abyad. Yet even then, what was being accounted for, and how, remains uncertain. Sets of small, alike or diverse clay objects may have been utilized in many numbers of ways, to aid in the counting, accounting and recording of all manner of things, not necessarily foodstuffs. Within administration, it is likely that clay objects operated as simple counting tools, not restricted to the administrative sphere, rather than for 
complex calculations or long-term information storage and transmission. There is certainly little evidence for the latter.

Outside the sphere of administration, a small proportion of clay objects were likely unfinished or crudely made beads, or figurine fragments in some cases (based on similarities between finished examples of beads/figurines to geometric clay objects at certain sites). Other clay objects could feasibly have functioned as gaming pieces. Gaming could have been undertaken as a leisure activity, or as part of social organization, with the outcome of the game used in decision making, the ration of resources, or interpreted as divination and sortation within the realms of ritual practice. Stone gaming boards are known in the Neolithic, with rows of depressions for counters matching the average size of clay objects. These boards hint that gaming was a widespread pastime (Bennison-Chapman 2014, chapter 2.3b). The origins of writing and its precursors need to be re-evaluated. Though it seems likely that within some communities, at some settlements, clay objects were used to count, these objects were not created as 'tokens' specifically to administer agricultural produce and were not part of a unified symbolic system. Nor were they essential tools within the world's first agricultural village societies. As objects, they operated with fluidity of function and interpretation, with imbued value and meaning.

\section{Acknowledgements}

Dr Bruce Routledge and Prof. Douglas Baird, University of Liverpool; Prof. Akkermans and Merel Brüning of the Tell Sabi Abyad Research Project, University of Leiden; Prof. Ian Hodder (Project Director), Shahina Farid (Field Director and Project Coordinator 1995-2012) and Prof. Lynn Meskell (Figurine Specialist), Çatalhöyük Research Project; Prof. Gary Rollefson and Dr Zeidan Kafafi, 'Ain Ghazal Excavation Project; the British Institute in Ankara (BIAA) and the Council for British Research in the Levant (CBRL). 


\section{References}

Akkermans, P.M.M.G. (ed.), 1989. Excavations at Tell Sabi Abyad: Prehistoric investigations in the Balikh Valley, northern Syria. (BAR International series S468.) Oxford: British Archaeological Reports.

Akkermans, P.M.M.G., 1993. The Excavations in the Balikh Valley, in Villages in the Steppe: Later Neolithic settlement and subsistence in the Balikh Valley, northern Syria. Ann Arbor (MI): International Monographs in Prehistory, 26-109.

Akkermans, P.M.M.G. (ed.), 1996a. Tell Sabi Abyad, The Late Neolithic Settlement: Report on the excavations of the University of Amsterdam (1988) and the National Museum of Antiquities Leiden (1991-1993) in Syria, Volume I. Istanbul:

Nederlands Historisch-Archaeologisch Instituut te Istanbul.

Akkermans, P.M.M.G. (ed.), 1996b. Tell Sabi Abyad, the Late Neolithic Settlement: Report on the excavations of the University of Amsterdam (1988) and the National Museum of Antiquities Leiden (1991-1993) in Syria, Volume II. Istanbul: Nederlands Historisch-Archaeologisch Instituut te Istanbul.

Akkermans, P.M.M.G., Cappers, R., Cavallo, C., Nieuwenhuyse, O., Nilhamn, B. \& Otte, I.N. 2006. "Investigating the Early Pottery Neolithic of Northern Syria: New evidence from Tell Sabi Abyad." American Journal of Archaeology 110/1(Jan), 23-56.

Akkermans, P.M.M.G., M. Brüning, N. Hammers, et al., 2012. Burning down the house: the burnt building V6 at Late Neolithic Tell Sabi Abyad, Syria. Analecta Praehistorica Leidensia 43(44), 307-24.

Akkermans, P.M.M.G., M.L. Brüning, H.O. Huigens \& O.P. Nieuwenhuyse (eds.), 2014. Excavations at Late Neolithic Tell Sabi Abyad: The 1994-1999 field seasons. Turnhout: Brepols.

Akkermans, P.M.M.G. \& K. Duistermaat, 1996. Of storage and nomads. The sealings from Late Neolithic, Sabi Abyad, Syria [with comments and reply]. Paléorient 22(2), 17-44. 
Akkermans, P.M.M.G. \& K. Duistermaat, 2004. More seals and sealings from Neolithic Tell Sabi Abyad, Syria. Levant 36, 1-11.

Akkermans, P., J. van der Plicht, O. Nieuwenhuyse, A. Russell, A. Kaneda \& H. Buitenhuis, 2010. Weathering climate change in the Near East: dating and Neolithic adaptations 8200 years ago. Antiquity 84(325), Project Gallery. Akkermans, P.M.M.G. \& M. Verhoeven, 1995. An image of complexity: the burnt village at Late Neolithic Sabi Abyad, Syria. American Journal of Archaeology 99(1), 5-32.

Amiet, P., 1966. Elam. Auvers-Sur-Oise: Archée.

Atalay, S., 2012. Analysis of clay balls from the BACH Area, in Last House on the Hill: BACH Area reports from Çatalhöyük, Turkey, eds. R. Tringham \& M. Stevanovic. (Monumenta Archaeologica 27.) Los Angeles (CA): Cotsen Institute of Archaeology at UCLA, 14/1-14/9.

Baird, D., 2002. Early Holocene settlement in Central Anatolia: problems and prospects as seen from the Konya Plain, in The Neolithic of Central Anatolia: Internal developments and external relations during the ninth-sixth millennia $C A L$ BC. Proceedings of the International CANeW Table Ronde, Istanbul, 23-24 November 2001, eds. F. Gérard \& L. Thissen. Istanbul: Ege Yayinlari, 139-60.

Baird, D., 2006. The Boncuklu Project: the origins of sedentism, cultivation and herding in Central Anatolia. Anatolian Archaeology 12, 13-16.

Baird, D., 2007. The Boncuklu project: the origins of sedentism, cultivation and herding in central Anatolia. Anatolian Archaeology 13, 14-17.

Baird, D., 2009. The Boncuklu Project: investigating the beginnings of agriculture, sedentism and herding in central Anatolia. Anatolian Archaeology 15, 9-10.

Baird, D., 2010. The Boncuklu Project: investigating the beginnings of agriculture, sedentism and herding in central Anatolia. Anatolian Archaeology 16, 9-11.

Baird, D., 2012a. The Late Epipalaeolithic, Neolithic and Chalcolithic of the Anatolian Plateau, 13,000-4000 BC, in A Companion to the Archaeology of the Ancient Near East, ed. D.T. Potts. Oxford: Wiley-Blackwell, 431-65. 
Baird, D., 2012b. The Boncuklu Project. Heritage Turkey 2, 16-18.

Baird, D. (ed.), forthcoming. Boncuklu Höyük volume I: A: preliminary report 2004-2010 seasons.

Baird, D., A. Fairbairn, L. Martin \& C. Middleton, 2012. The Boncuklu Project; the origins of sedentism, cultivation and herding in central Anatolia, in The Neolithic in Turkey: New excavations and new research. Vol. 3: Central Anatolia, eds. M. Özdoğan, N. Başgelen \& P. Kuniholm. Istanbul: Arkeoloji ve Sanat Yayinlar, 219-44.

Baird, D., O. Bar-Yosef, A. Baysal \& A. Fairbairn, 2011. The Boncuklu Project: the origins of sedentism, cultivation and herding in central Anatolia. Heritage Turkey 1, 15-16.

Bartl, K., J. Ramadan \& W. Al-Hafian, 2011. Shir/West Syria. Results of the sixth and seventh seasons of excavations in 2009. Chronique Archéologique en Syrie 5, 5160.

Bender, B., 1978. Gatherer-hunter to farmer: a social perspective. World Archaeology 10(2), 204-22.

Bennison-Chapman, L.E., 2013. Geometric clay objects, in Substantive Technologies at Çatalhöyük: Reports from the 2000-2008 seasons, ed. I. Hodder. (Çatalhöyük Research Project 9.) London/Los Angeles: British Institute at Ankara/Cotsen Institute of Archaeology at UCLA, 253-76.

Bennison-Chapman, L.E., 2014. The Role and Function of Tokens and Sealing Practices in the Neolithic of the Near East: The Question of Early Recording Systems, Symbolic Storage, Precursors to Writing, Gaming, or Monitoring Devices in the World's First Villages. Unpublished PhD dissertation, University of Liverpool.

Binford, L.R., 1968. Post-Pleistocene adaptations, in New Perspectives in Archaeology, eds. S. Binford \& L. Binford. Chicago (IL): Aldine, 331-41. 
Bottéro, J., C. Herrenschmidt \& J.P. Vernant, 2000. Ancestor of the West: Writing, reasoning, and religion in Mesopotamia, Elam, and Greece. Chicago/London: University of Chicago Press.

Braidwood, R.J., 1960. The agricultural revolution. Scientific American 203, 130-48.

Broman, V., 1958. Jarmo Figurines. Unpublished Masters dissertation, University of Cambridge.

Broman Morales, V., 1990. Figurines and Other Clay Objects from Sarab and Çayönü. Chicago (IL): Oriental Institute of the University of Chicago.

Brown, S., 1996. Review of Schmandt-Besserat, D. Before Writing, Volumes I E II, 1992. Canadian Society for Mesopotamian Studies Bulletin 31, 35-43.

Byrd, B.F., 2005. Reassessing the emergence of village life in the Near East. Journal of Archaeological Research 13(3), 231-90.

Çambel, H. \& R.J. Braidwood, 1979. An early farming village in Turkey, in Readings from Scientific American. Hunters, farmers, and civilizations: Old World archaeology with introductions by C.C. Lamberg-Karlovsky. San Francisco (CA): W.H. Freeman, 145-51. [Originally published in Scientific American, March 1970.]

Carter, E., 2010. The Glyptic of the Middle-Late Halaf Period at Domuztepe, Turkey (ca 5755-5450 BC). Paléorient 36(1), 159-77.

Cauvin, J., 1994. Naissance des divinités, naissance de l'agriculture: la révolution des symboles au Néolithique. Paris: CNRS.

Cauvin, J., 2000. The Birth of the Gods and the Origins of Agriculture (trans.T. Watkins). Cambridge: Cambridge University Press.

Cessford, C., 2005. Absolute dating at Çatalhöyük, in Changing Materialities at Çatalhöyük: Reports from the 1995-99 seasons, ed. I. Hodder. (Çatalhöyük Research Project 5.) Cambridge/London: McDonald Institute for Archaeological Research/British Institute of Archaeology at Ankara, 65-99.

Childe, V.G., 1928. The Most Ancient Near East. New York (NY): Grove Press. Childe, V.G., 1936. Man Makes Himself. London: Watts. 
Çilingiroğlu, A., Z. Derin, E. Abay, H. Sağlamtimur \& I. Kayan, 2004. Ulucak Höyük: Excavations conducted between 1995 and 2002. Louvain: Peeters.

Clarke, D.L., 1973. Archaeology: the loss of innocence. Antiquity 47, 6-18.

Cole, G., R. Matthews \& A. Richardson, 2013. Material networks of the Neolithic at Sheikh-e Abad: objects of bone, stone and clay, in The Earliest Neolithic of Iran: 2008 excavations at Sheikh-e Abad and Jani, eds. R. Matthews, Y. Mohammadifar \& W. Matthews. (CZAP Reports Vol. 1.) Oxford: Oxbow, 135-45.

Coolidge, L. \& K. Overmann, 2012. Numerosity, abstraction, and the emergence of symbolic thinking. Current Anthropology 53(2), 204-25.

Cooper, J. S., 2004. Babylonian beginnings: the origin of the cuneiform writing system, in comparative perspective, in The First Writing: Script invention as history and process, ed. S.D. Houston. Cambridge: Cambridge University Press, 71-99.

Costello, S.K., 2000. Memory tools in early Mesopotamia. Antiquity 74, 475-6.

Costello, S.K., 2002. Tools of Memory: Investigation of the Context of Information. Storage in the Halaf Period. Unpublished PhD dissertation, Binghamton University.

Coulmas, F., 2003. Writing Systems: An introduction to their linguistic analysis. Cambridge: Cambridge University Press.

d'Errico, F., C. Henshilwood, G. Lawson, et al., 2003. Archaeological evidence for the emergence of language, symbolism, and music - an alternative multidisciplinary perspective. Journal of World Prehistory 17(1), 1-70.

Damerow, P. 1988. "Individual Development and Historical Evolution of Arithmetical Thinking" in Ontogeny, Phylogeny, and Historical Development, ed. S. Strauss, Ablex Publishing Corp., Northwood, 125-52.

Damerow, P., 1993. Bookkeepers invented scripture: review of Schmandt-Besserat's Before Writing 1992. Rechtshistorisches Journal 12(6), 9-35. 
Damerow, P., 2006. The origins of writing as a problem of historical epistemology. Cuneiform Digital Library Journal 2006(1), 1-10.

Damerow, P. \& Englund, R.K. 1987. "Die Zahlzeichensysteme der Archaischen Texte aus Uruk" in Zeichenliste der Archaischen Texte aus Uruk, eds. H.J. Nissen \& M.W. Green, Gebr.Mann Verlag, Berlin, 117-66.

Doyle, S. 2017. Chipped stone from the North and South Areas, in Çatalhöyük Archive Report 2017, 195-206. Available at:

http://www.catalhoyuk.com/archive_reports/2017 (accessed 5 October 2018).

Duistermaat, K., 1996. The seals and sealings, in Tell Sabi Abyad, The Late Neolithic Settlement: Report on the excavations of the University of Amsterdam (1988) and the National Museum of Antiquities Leiden (1991-1993) in Syria vol II, ed. P.M.M.G. Akkermans. Istanbul: Nederlands Historisch-Archaeologisch Instituut te Istanbul, 339-402.

Duistermaat, K. \& G. Schneider, 1998. Chemical analyses of sealing clays and the use of administrative artefacts at Late Neolithic Tell Sabi Abyad (Syria). Paléorient 24(1), 89-106.

Duru, R. \& G. Umurtak, 2005. Höyücek. 1989-1992 Yillari Arasinda Yapilan Kazilarin Sonuçlari 2005 [Höyücek. Results of the Excavations 1988-1992]. Ankara: Türk Tarih Kurumu Yayinlari.

Englund, R.K., 1993. The origins of script. Review of Before Writing by Denise Schmandt-Besserat. Science 260(5114), 1670-71.

Englund, R.K., 1998. Review of D. Schmandt-Besserat, How Writing Came About. Written Language and Literacy 1, 257-61.

Englund, R.K., 2004. The state of decipherment of Proto-Elamite, in The First Writing: Script invention as history and process, ed. S.D. Houston. Cambridge: Cambridge University Press, 100-149.

Eslick, C. \& M.M. Voigt, 2017. Some clay finds from PPNB Gritille: stamps, sealings and tokens in questions, approaches, and dialogues, in Eastern Mediterranean 
Archaeology Studies in honor of Marie Henriette and Charles Gates, eds. E. Kozal, M. Akar, Y. Heffron, et al. Münster: Ugarit-Verlag, 77-96.

Fischer, S.R., 2001. A History of Writing. London: Reaktion Books.

Forouzan, F., J.B. Glover, F. Williams \& D. Deocampo, 2012. Portable XRF analysis of zoomorphic figurines, 'tokens,' and sling bullets from Chogha Gavaneh, Iran. Journal of Archaeological Science 39(12), 3534-41.

Friberg, J., 1994. Preliterate counting and accounting in the Middle East: a constructively critical review of Schmandt-Besserat's Before Writing. Orientalistische Literaturzeitung 89(5-6), 477-502.

Garfinkel, Y. 1995. Human and animal figurines of Munhata, Les Cahiers des Missions Archéologiques Francaises en Israel (Volume 8), Association Paléorient, Paris.

Hayden, B., 1990. Nimrods, piscators, pluckers, and planters: the emergence of food production. Journal of Anthropological Archaeology 9(1), 31-69.

Henshilwood, C.S., F. d'Errico \& I. Watts, 2009. Engraved ochres from the Middle Stone Age levels at Blombos Cave, South Africa. Journal of Human Evolution 57, $27-47$.

Herskovits, M.J., 1932: Population statistics in the Kingdom of Dahomey. Human Biology 4(2), 252-61.

Hodder, I., 1995. Çatalhöyük. Anatolian Archaeology 1, 3-5.

Hodder, I. (ed.), 1996a. On the Surface: Çatalhöyük 1993-95 (Çatalhöyük Research

Project 1). Cambridge/London: McDonald Institute for Archaeological

Research/British Institute of Archaeology at Ankara.

Hodder, I., 1996b. Çatalhöyük. Anatolian Archaeology 2, 6-7.

Hodder, I., 1997. Çatalhöyük. Anatolian Archaeology 3, 4-5.

Hodder, I., 1998. Çatalhöyük: The 1990's seasons, in Ancient Anatolia: Fifty years' work by the British Institute of Archaeology at Ankara, ed. R. Matthews. London: British Institute at Ankara, 43-52. 
Hodder, I., 1999a. Renewed work at Çatalhöyük, in Neolithic in Turkey: The cradle of civilization (Vol. 1), eds. M. Özdoğan \& N. Basgelen. Istanbul: Arkeoloji ve Sanat Yayinlari, 157-64.

Hodder, I., 1999b. Renewed Work at Çatalhöyük, in Neolithic in Turkey: The cradle of civilization (Vol. 2), eds. M. Özdoğan \& N. Basgelen. Istanbul: Arkeoloji ve Sanat Yayinlari, 129-35.

Hodder, I., 2000. Towards a Reflexive Method in Archaeology: The example at Çatalhöyük. (Çatalhöyük Research Project 2.) Cambridge/London: McDonald Institute for Archaeological Research/British Institute of Archaeology at Ankara.

Hodder, I., 2001. Çatalhöyük. Anatolian Archaeology 7, 2-4.

Hodder, I., 2002. Çatalhöyük. Anatolian Archaeology 8, 5-7.

Hodder, I., 2004. A season of great finds and new faces at Çatalhöyük. Anatolian Archaeology 10, 8-10.

Hodder, I., 2005a. New finds and new interpretations at Çatalhöyük. Anatolian Archaeology 11, 20-22.

Hodder, I., 2005b. Yearly reports continue in Anatolian Archaeology 12-16 (2006-2010) and its replacement publication Heritage Turkey 1 (2011-ongoing).

Hodder, I. (ed.), 2005c. Inhabiting Çatalhöyük: Reports from the 1995-99 seasons. (Çatalhöyük Research Project 4.). Cambridge/London: McDonald Institute for Archaeological Research/British Institute of Archaeology at Ankara.

Hodder, I. (ed.), 2005d. Changing Materialities at Çatalhöyük: reports from the 1995-99 seasons (Çatalhöyük Research Project 5.) Cambridge/London: McDonald Institute for Archaeological Research/British Institute of Archaeology at Ankara.

Hodder, I. (ed.), 2005e. Çatalhöyük perspectives: reports from the 1995-99 seasons (Çatalhöyük Research Project 6.) Cambridge/London: McDonald Institute for Archaeological Research/British Institute of Archaeology at Ankara.

Hodder, I., 2006a. Çatalhöyük. The Leopard's Tale: Revealing the mysteries of Turkey's ancient 'town'. London: Thames \& Hudson. 
Hodder, I., 2006b. Excavating Çatalhöyük: South, North and KOPAL Area reports from the 1995-99 seasons (Çatalhöyük Research Project 3.) Cambridge/London: McDonald Institute for Archaeological Research/British Institute of Archaeology at Ankara.

Hodder, I., 2010. Religion in the Emergence of Civilisation: Çatalhöyük as a case study. Cambridge/New York: Cambridge University Press.

Hodder, I. (ed.), 2013a. Humans and Landscapes of Çatalhöyük: Reports from the 20002008 seasons. (Çatalhöyük Research Project 8.) London/Los Angeles: British Institute at Ankara/Cotsen Institute of Archaeology at UCLA.

Hodder, I. (ed.), 2013b. Substantive Technologies at Çatalhöyük: Reports from the 20002008 seasons. (Çatalhöyük Research Project 9.) London/Los Angeles: British Institute at Ankara/Cotsen Institute of Archaeology at UCLA.

Hodder, I. (ed.), 2014a. Çatalhöyük Excavations, the 2000-2008 seasons. (Çatalhöyük Research Project 7.) London/Los Angeles: British Institute at Ankara/Cotsen Institute of Archaeology at UCLA.

Hodder, I. (ed.), 2014b. Integrating Çatalhöyük: Themes from the 2000-2008 seasons. (Çatalhöyük Research Project 10.) London/Los Angeles: British Institute at Ankara/Cotsen Institute of Archaeology at UCLA.

Hodder, I., C. Cessford \& S. Farid, 2006. Introduction to methods and approach, in Excavating Çatalhöyük: South, North and KOPAL Area reports from the 1995-99 seasons, ed. I. Hodder. (Çatalhöyük Research Project 3.) Cambridge/London: McDonald Institute for Archaeological Research/British Institute at Ankara, 324.

Hole, F., 2000. Is size important? Function and hierarchy in Neolithic settlements, in Life in Neolithic Farming Communities: Social organization, identity, and differentiation, ed. I. Kuijt. New York/London: Kluwer Academic/Plenum, 192209. 
Houston, S., 2004. Overture to the first writing, in The First Writing: Script invention as history and process, ed. S.D. Houston. Cambridge: Cambridge University Press, 3-15.

Iceland, H. 2010a. “Chapter 1: Token Finds at Pre-Pottery Neolithic 'Ain Ghazal, Jordan: A Formal and Technological Analysis" in 'Ain Ghazal Excavation Reports Volume 2: Symbols at 'Ain Ghazal. Ed. D. Schmandt-Besserat. Published under the direction of Gary O. Rollefson and Zeidan Kafafi. Available at: http: //www. laits. utexas. edu/ghazal/Chap1/chapter1. html. (accessed 14 April 2012).

Iceland, H. 2010b. “Appendix to Chapter 1: Catalogue "in 'Ain Ghazal Excavation Reports Volume 2: Symbols at 'Ain Ghazal. Ed. D. Schmandt-Besserat. Published under the direction of Gary O. Rollefson and Zeidan Kafafi. Available at: http: /Wwww. laits. utexas. edu/ghazal/Chap1/chapter1. html. (accessed 14 April 2012).

Jasim, S. A. \& Oates, J. 1986. "Early Tokens and Tablets in Mesopotamia: New Information from Tell Abada and Tell Brak", World Archaeology, vol. 17(3), 348362.

Jenkinson, H. \& R.H. Ellis, 2003. Medieval tallies, public and private, in Selected Writings of Sir Hilary Jenkinson, eds. R.H. Ellis \& P. Walne. Society of American Archivists, 289-351. [Originally published in Archaeologica, 2nd series, XXIV, 1925.]

Jørgensen, L.B. \& A. Rast-Eicher, 2017. Cordage, basketry, textiles and hides, in Çatalhöyük Archive Report 2017, 181-3. Available at: http://www.catalhoyuk.com/archive_reports/2017 (accessed 5 October 2018).

Kenyon, K.M. \& T.A. Holland, 1983. Excavations at Jericho Volume 5: The pottery phases of the Tell and other finds. London: British School of Archaeology in Jerusalem/British Academy.

Kuijt, I. \& Chesson, M. S. 2005. "Lumps of clay and pieces of stone: ambiguity, bodies, and identity as portrayed in Neolithic figurines" in Archaeologies of the 
Middle East: critical perspectives, eds. S. Pollock \& R. Bernbeck, Blackwell, Oxford, 152-83.

Lee, R.B. \& I. DeVore, 1968. Man the Hunter. Chicago (IL): Aldine.

Leo Oppenheim, A., 1959. On an operational device in Mesopotamian bureaucracy. Journal of Near Eastern Studies 18(2), 121-8.

Lingle, A. \& J. Seifert, 2017. Conservation, in Çatalhöyük Archive Report 2017, 261-8.

Available at: http://www.catalhoyuk.com/archive_reports/2017 (accessed 5 October 2018).

MacGinnis, J. 2013. Tablets and Tokens on the Border of Assyria. Paper presented at the British Association of Near Eastern Archaeologists (BANEA) Annual Conference, University of Cambridge, 5 January 2013.

Mahasneh, H.M. \& H.G. Gebel, 1998. Geometric objects from LPPNB Es-Sifiya, Wadi Mujib, Jordan. Paléorient 24(2), 105-10.

Malafouris, L., 2010. Grasping the concept of number: how did the sapient mind move beyond approximation?, in The Archaeology of Measurement: Comprehending heaven, earth and time in ancient societies, eds. C. Renfrew \& I. Morley. Cambridge: Cambridge University Press, 35-42.

Malafouris, L., 2013. How Things Shape the Mind: A theory of material engagement. Cambridge/London: MIT Press.

Marshack, A. 1991. The Taï plaque and calendrical notation in the Upper Palaeolithic. Cambridge Archaeological Journal 1(1), 25-61.

Matthews, R., W. Matthews \& Y. Mohammadifar (eds.), 2013. The Earliest Neolithic of Iran: 2008 excavations at Sheikh-E Abad and Jani. Oxford: Oxbow.

Mellaart, J., 1962. Excavations at Çatal Hüyük, 1961: first preliminary report. Anatolian Studies 12, 41-65.

Mellaart, J., 1963. Excavations at Çatal Hüyük, 1962: second preliminary report. Anatolian Studies 13, 43-103.

Mellaart, J., 1964a. Excavations at Çatal Hüyük, 1963: third preliminary report. Anatolian Studies 14, 39-119. 
Mellaart, J., 1964b. A Neolithic city in Turkey. Scientific American 1964, 94-104.

Mellaart, J., 1965a. Çatal Hüyük, in Earliest Civilizations of the Near East, by J. Mellaart. London: Thames \& Hudson, 81-101.

Mellaart, J., 1965b. Çatal Hüyük: a Neolithic city in Anatolia. Proceedings of the British Academy 51, 201-13.

Mellaart, J., 1966. Excavations at Çatal Hüyük, 1965: fourth preliminary report. Anatolian Studies 16, 165-91.

Mellaart, J., 1967. Çatal Hüyük: A Neolithic town in Anatolia. London: Thames \& Hudson.

Mellaart, J., 1975. Anatolia and Cyprus, in The Neolithic of the Near East, by J. Mellaart. London: Thames \& Hudson, 91-134.

Mellaart, J., 1978. Çatal Hüyük: the Neolithic revolution, in The Archaeology of Ancient Turkey, by J. Mellaart. London/Sydney/Toronto: The Bodley Head, 9-22.

Michalowski, P., 1990. Early Mesopotamia communicative systems: art, literature, and writing, in Investigating Artistic Environments in the Ancient Near East, ed. A.C. Gunter. Washington/Madison: Arthur M. Sackler Gallery, 53-69.

Michalowski, P. 1993. “Review: Tokenism: Before Writing, Volume 1: From Counting to Cuneiform by Denise Schmandt-Besserat; Before Writing, Volume 2: A Catalog of Near Eastern Tokens by Denise Schmandt-Besserat", American Anthropologist, 95(4), 996-999.

Michalowski, P., 1994. Writing and literacy in early states: a Mesopotamianist perspective, in Literacy: Interdisciplinary conversations, ed. D. Keller-Cohen. Cresskill (NJ): Hampton Press, 49-70.

de Morgan, J., Jéquier, G., de Mecquenem, R., Haussoulier, B. \& Graat van Roggen, D.-L. 1905. Mémoires de la Délégation en Perse, 7, Recherches archéologiques, zème série, Editions Ernst Le Roux, Paris. 
Nashli, H.F. \& N. Moghimi, 2013. Counting objects: new evidence from Tepe Zagheh, Qazvin plain, Iran. Antiquity 87(336), Project Gallery.

Netz, R., 2002. Counter culture: towards a history of Greek numeracy. History of Science 40(3), 321-52.

Nieuwenhuyse, O.P., P.M.M.G. Akkermans \& J. van der Plicht, 2010. Not so coarse, nor always plain - the earliest pottery of Syria. Antiquity 84, 71-85.

Nissen, H.J., 1986. The archaic texts from Uruk. World Archaeology 17(3), 319-33.

Nissen, H.J., P. Damerow \& R.K. Englund, 1993. Archaic Bookkeeping: Early writing and techniques of economic administration in the ancient Near East. Chicago (IL): University of Chicago Press.

Overmann, K., 2013. Material scaffolds in numbers and time. Cambridge Archaeological Journal 23(1), 19-39.

Overmann, K., 2015. Numerosity structures the expression of quantity in lexical numbers and grammatical number. Current Anthropology 56(5), 638-53.

Overmann, K., 2016. Beyond writing: the development of literacy in the Ancient Near East. Cambridge Archaeological Journal 26(2), 285-303.

Overmann, K., T. Wynn \& F.L. Coolidge, 2011. The prehistory of number concept. Behavioural Sciences 34, 142-4.

Özbal, R., F. Gerritsen, B. Diebold, et al., 2004. Tell Kurdu excavations 2001. Anatolica 30, 37-107.

Pim, J.E., S.A. Yatsenko \& O.T. Perrin, 2010. Traditional Marking Systems: A preliminary survey. Dover: Dunkling Books.

Pollock, S., 1999. Ancient Mesopotamia: The Eden that never was. Cambridge: Cambridge University Press.

Price, T.D. \& A.B. Gebauer (eds.), 1995. Last Hunters, First Farmers: New perspectives on the prehistoric transition to agriculture. Santa Fe (NM): School of American Research Press.

Quilter, J. \& G. Urton, 2002. Narrative Threads: Accounting and recounting in Andean khipu. Austin (TX): University of Texas Press. 
Redman, C., 1977. Man, domestication, and culture in southwestern Asia, in Origins of Agriculture, ed. C.A. Reed. The Hague/Paris: Mouton, 523-42.

Richardson, A. 2014. Early clay technologies: studies in Early Neolithic clay usage from the Central Zagros, in Proceedings of the 8th ICAANE, 30th April-4th May 2012, University of Warsaw, Vol. 1. Wiesbaden: Harrassowitz, 41-53.

Robinson, A., 2007. The Story of Writing: Alphabets, hieroglyphs and pictograms. London: Thames \& Hudson.

Rollefson, G., A.H. Simmons \& Z. Kafafi, 1992. Neolithic Cultures at 'Ain Ghazal, Jordan. Journal of Field Archaeology 19(4), 443-70.

Schmandt-Besserat, D., 1977. An Archaic Recording System and the Origin of Writing. Malibu (CA): Undena Publications.

Schmandt-Besserat, D., 1978a. The earliest precursor of writing. Scientific American 238(6), 50-59.

Schmandt-Besserat, D., 1978b. Reckoning before writing. Archaeology 32(3), 22-31.

Schmandt-Besserat, D., 1979. An archaic recording system in the Uruk-Jemdet Nasr period. American Journal of Archaeology 83(1), 19-48.

Schmandt-Besserat, D., 1980. The envelopes that bear the first writing. Technology and Culture 21(3), 357-85.

Schmandt-Besserat, D., 1981. From tokens to tablets: a re-evaluation of the so-called numerical tablets. Visible Language 15(4), 321-44.

Schmandt-Besserat, D., 1982a. How writing came about. Zeitschrift für Papyrologie und Epigraphik 47, 1-5.

Schmandt-Besserat, D., 1982b. The emergence of recording. American Anthropologist 84(4), 871-8.

Schmandt-Besserat, D., 1988. From accounting to written language: the role of abstract counting in the invention of writing, in The Social Construction of Written Communication (Writing Research), eds. B.A. Raforth \& D.L. Rubin. New York (NY): Ablex Publishing, 119-30. 
Schmandt-Besserat, D., 1992a. Before Writing, Volume I: From counting to cuneiform. Austin (TX): University of Texas Press.

Schmandt-Besserat, D., 1992b. Before Writing, Volume II: A catalogue of Near Eastern tokens. Austin (TX): University of Texas Press.

Schmandt-Besserat, D., 1996. How Writing Came About. Austin (TX): University of Texas Press.

Simmons, A.H. \& M. Najjar, 2006. Ghwair I: a small, complex Neolithic community in southern Jordan. Journal of Field Archaeology 31(1), 77-95.

Simpson, S.J., 2007. Homo ludens: the earliest board games in the Near East, in Ancient Board Games in Perspective: Papers from the 1990 British Museum colloquium, with additional contributions, ed. I.L. Finkel. London: British Museum Press, 5-10.

Sy, A. \& T. Tinker, 2006. Bury Pacioli in Africa: a bookkeeper's reification of accountancy. Abacus 42(1), 105-27.

Tringham, R. \& M. Stevanovic (ed.), 2012. Last House on the Hill: BACH Area Reports from Çatalhöyük, Turkey. (Monumenta Archaeologica 27.) Los Angeles (CA): Cotsen Institute of Archaeology at UCLA.

Vallat, F., 1986. The most ancient scripts of Iran: the current situation. World Archaeology 17(3), 335-47.

Verhoeven, M., 1999. An Archaeological Ethnography of a Neolithic Community: Space, place and social relationships in the burnt village at Tell Sabi Abyad, Syria. Istanbul: Nederlands Historisch-Archaeologisch Instituut te Istanbul.

Verhoeven, M., 2000. Death, fire and abandonment. Ritual practice at Late Neolithic Tell Sabi Abyad, Syria. Archaeological Dialogues 7(1), 46-65.

Verhoeven, M., 2011. The birth of a concept and the origins of the Neolithic: a history of prehistoric farmers in the Near East. Paléorient 37(1), 75-87.

Verhoeven, M. \& P.M.M.G. Akkermans (eds.), 2000. Tell Sabi Abyad II: The Pre-Pottery Neolithic B settlement. Istanbul: Nederlands Historisch-Archaeologisch Instituut te Istanbul. 
Viteles, M.S., 1947. Charles Samuel Myers, 1873-1946. Psychological Review 54(4), 17781.

Voigt, M.M. 1983. Hajji Firuz Tepe, Iran: The Neolithic settlement. Philadelphia (PA):

University of Pennsylvania Museum of Archaeology \& Anthropology.

Watkins, T., 2010. New light on Neolithic Revolution in South-west Asia. Antiquity $84,621-34$.

Woods, C., 2010. The earliest Mesopotamian writing, in Visible Language: Inventions of writing in the ancient Middle East, ed. C. Woods. Chicago (IL): Oriental Institute of the University of Chicago, 33-84.

Woods, C., 2014. New Light on an Administrative Device from the Dawn of Writing in the Ancient Near East. Keynote speech, British Association of Near Eastern Archaeologists (BANEA) Annual Conference 2014, University of Reading, 9 January 2014.

Zimansky, P., 1993. Review of D. Schmandt-Besserat, 'Before Writing, Vol. I'. Journal of Field Archaeology 20, 513-17.

\section{Author biography}

Lucy Bennison-Chapman studied archaeology at the University of Liverpool, graduating in 2015. Her main research interest centres on the development of complex societies; the social developments that commenced with the appearance of sedentism and agriculture in Neolithic period; culminating in the appearance of the complex, literate city-states of West Asia in the third millennium BC. She has undertaken fieldwork in Syria, Kuwait and Turkey, where she remains an active team member of both the Çatalhöyük Research Project (directed by Prof. Ian Hodder, Stanford University) and the Boncuklu Höyük Project (directed by Prof. Baird, University of Liverpool), for which she has written numerous reports of the site's clay objects. She has recently returned to the UK having completed a two-year teaching and research position at Bülent Ecevit University, Zonguldak, Turkey. 


\section{ILLUSTRATIONS}

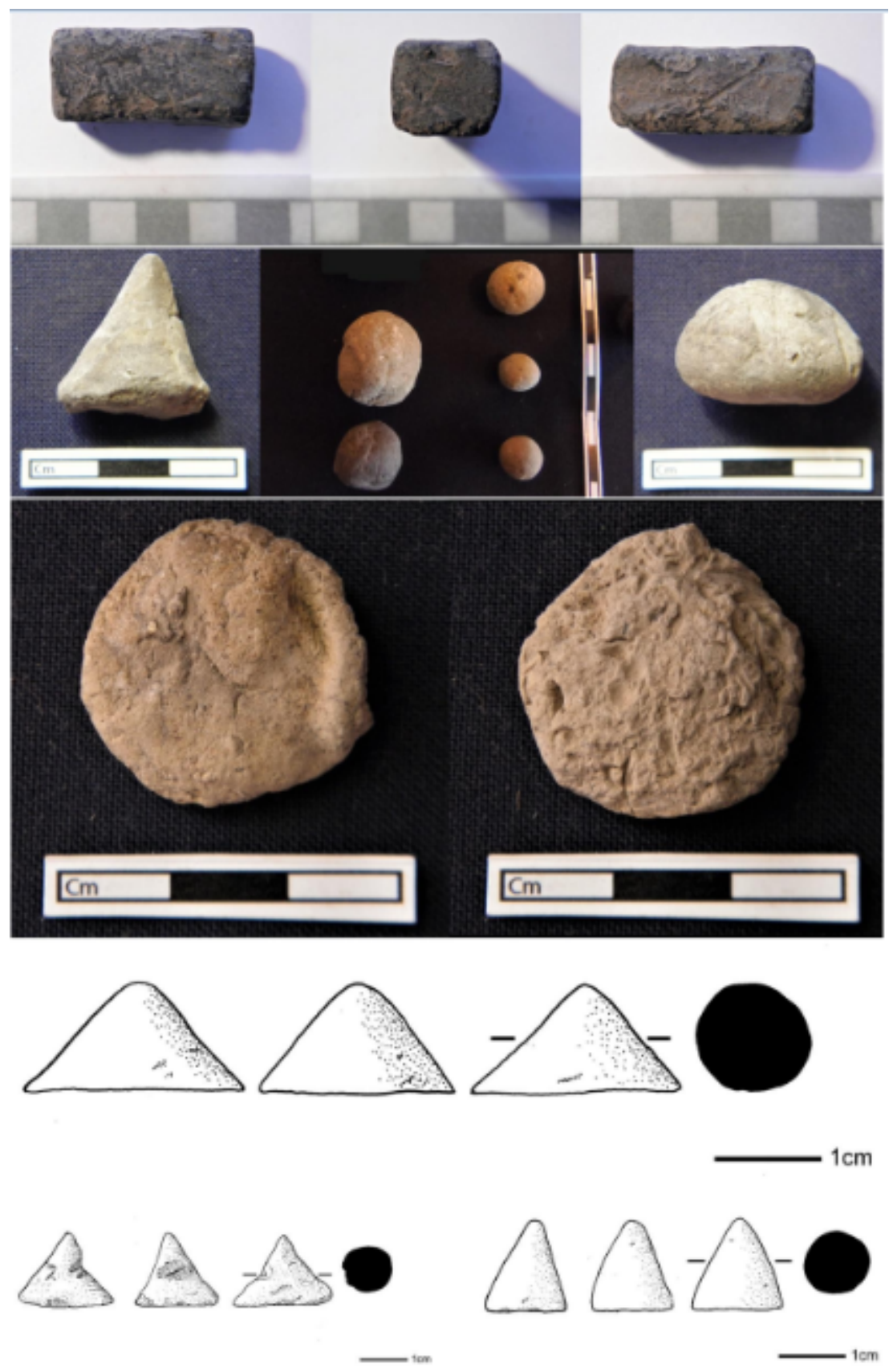

Figure 1. Examples of small geometric clay objects ('tokens') from various Neolithic sites in West Asia. All examples shown here fall into Schmandt-Besserat's (1992a,b; 1996) 'plain token' category. (a) Cuboid,

Çatalhöyük (East mound): CO\# [clay object number] 1283; (b) Triangular-shaped clay object, Boncuklu Höyük: CO\# 1483; (c) Sphere selection, Çatalhöyük: CO\# 344, 345 \& 346; (d) Semi-sphere, Boncuklu Höyük: CO\# 1515; (e) Front and reverse of disc, Boncuklu Höyük: CO\# 1440; (f) Cones, Çatalhöyük: CO\# 1080, 1120 \& 1151. (Photographs: author. Drawings: Mesa Schumacher, courtesy of the Çatalhöyük Project.) 


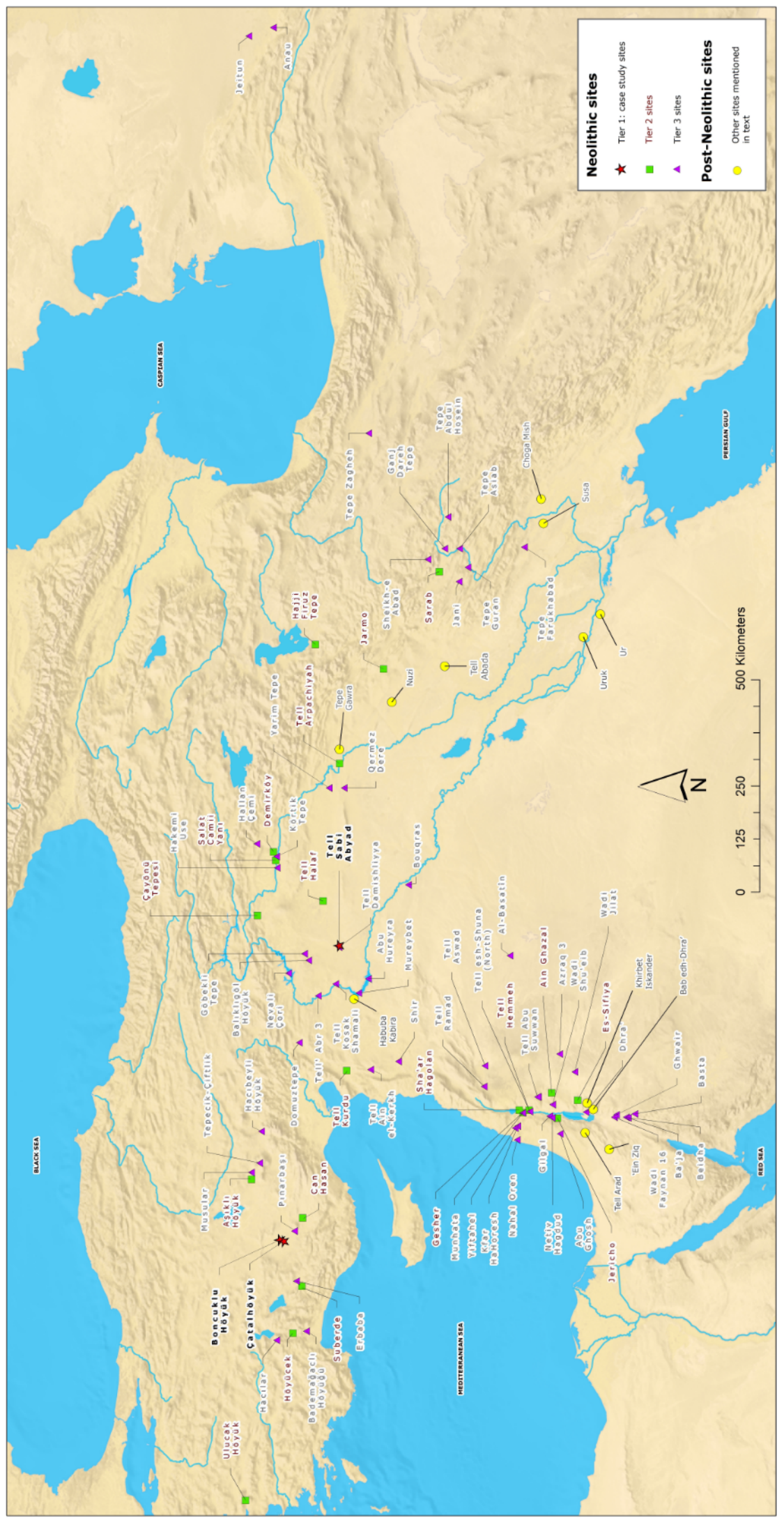

Figure 2. West Asia, showing the location of sites discussed in the text by detail or tier of study. (Map: made with Natural Earth vector and raster map data from @naturalearthdata.com, with the kind assistance of Dominic Baker.) 

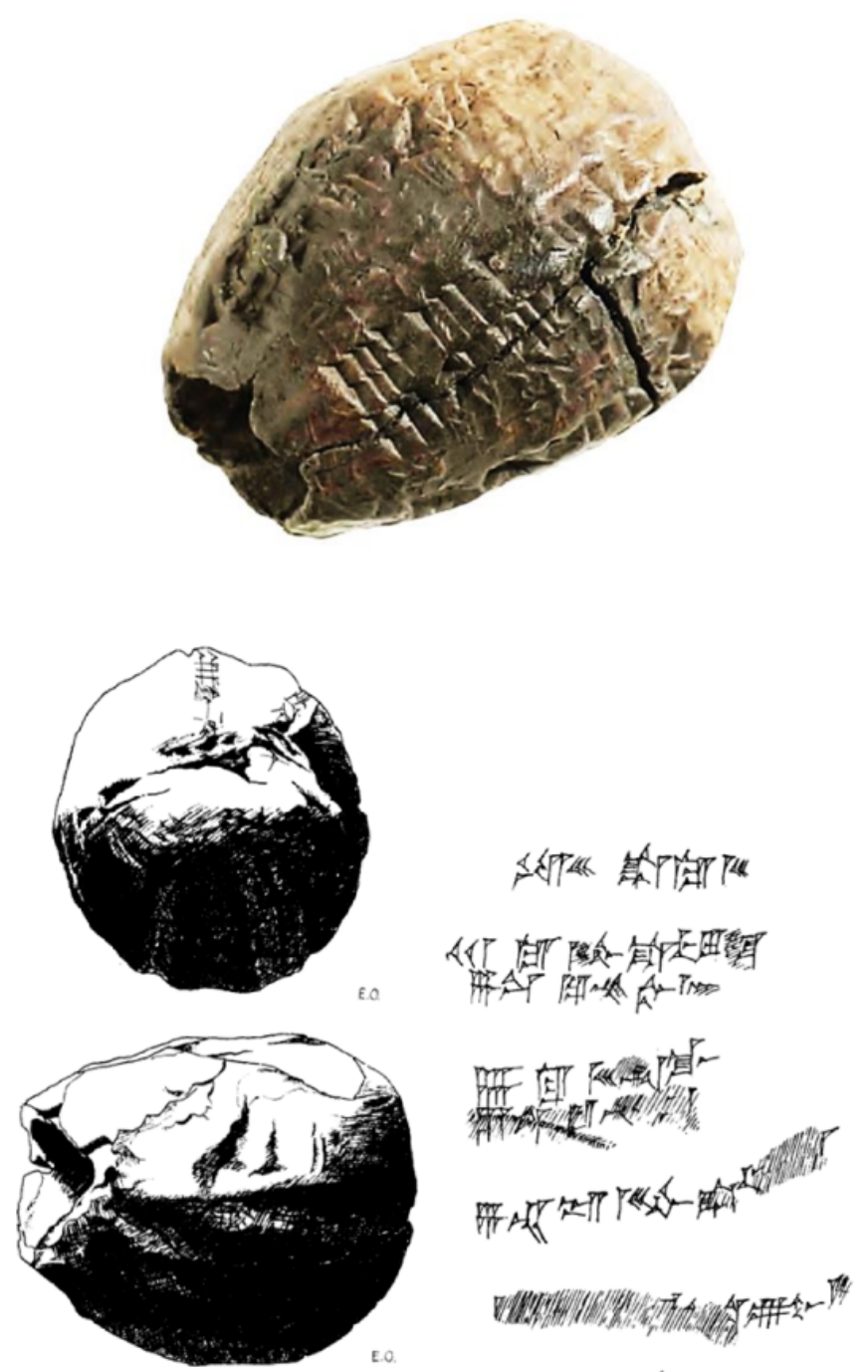

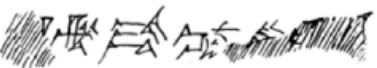

Figure 3. (Above) Hollow, egg-shaped clay envelope ('bulla') from Nuzi (adapted from Woods 2010, 46, fig.

2.13); (below) Drawing of a cast of Text 449 and detail of the eight lines of written text, an administrative cuneiform text from second-millennium BC Nuzi, modern Yorghan Tepe. (Leo Oppenheim 1959, 122, figs 1 \& 2.) 


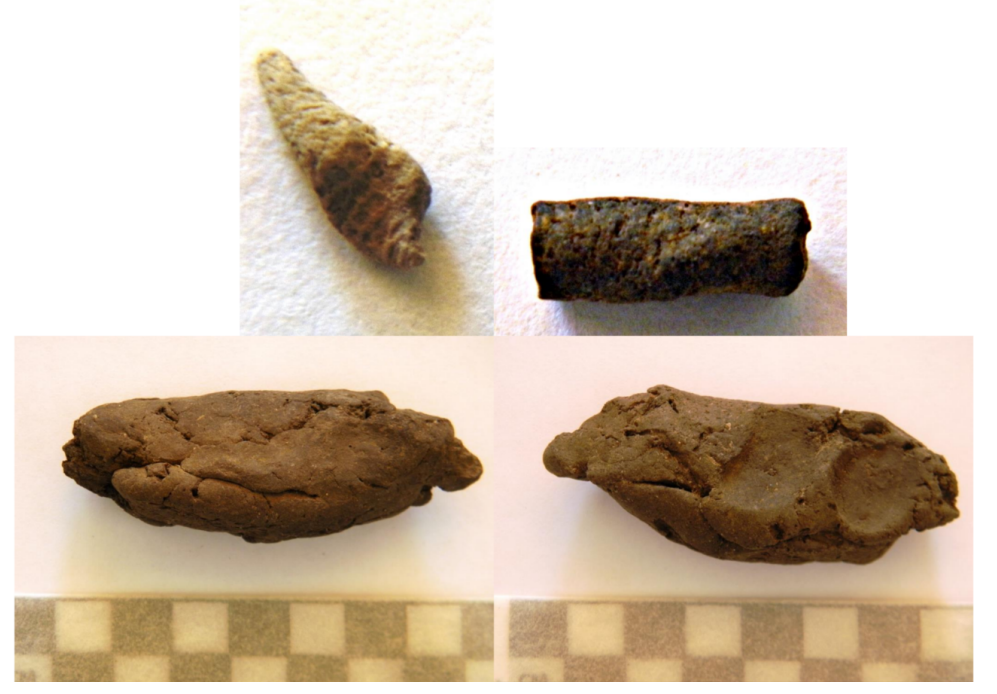

Figure 4. Examples of small clay artefacts, not recorded as geometric clay objects. (Top left) Probable figurine fragment (horn from a zoomorphic figurine, Çatalhöyük); (top right) Naturally-shaped cylindrical object (formed by clay/soil naturally drying inside reed, a common plant at Boncuklu Höyük, thus these clay formations are abundant at the site); (below) Clay has clearly been manipulated by a human hand, with fingerprints and fingertip depressions evident, Çatalhöyük. However, it has not been intentionally formed into a recognizable geometric shape. (Photographs: author.) 

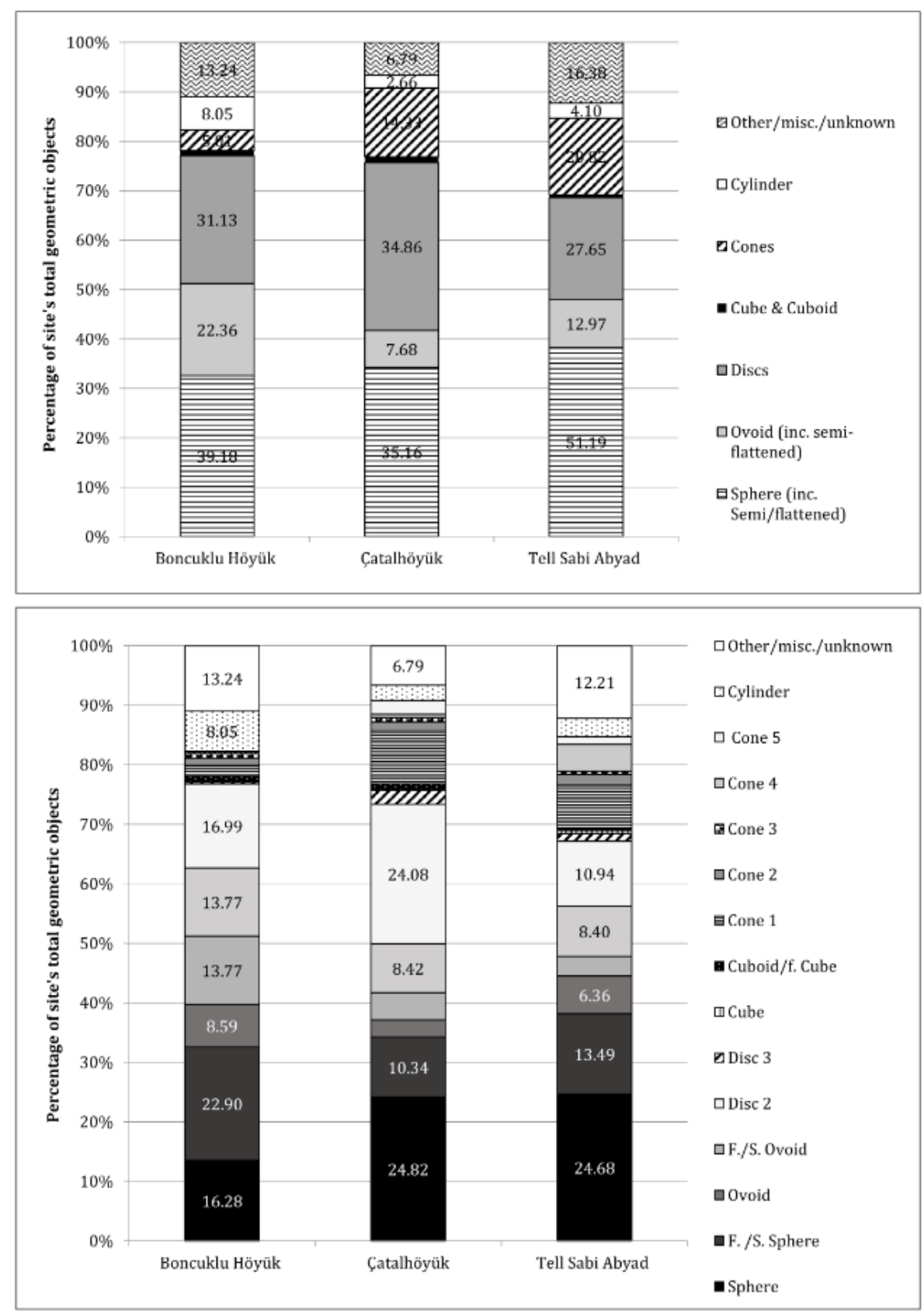

Figure 5. Comparison of the range and proportion of three-dimensional shapes represented by the clay object assemblages of the case-study sites. (Above) Basic shape and (below) detailed shape (shapes representing five per cent or greater of a site's assemblage are detailed). 

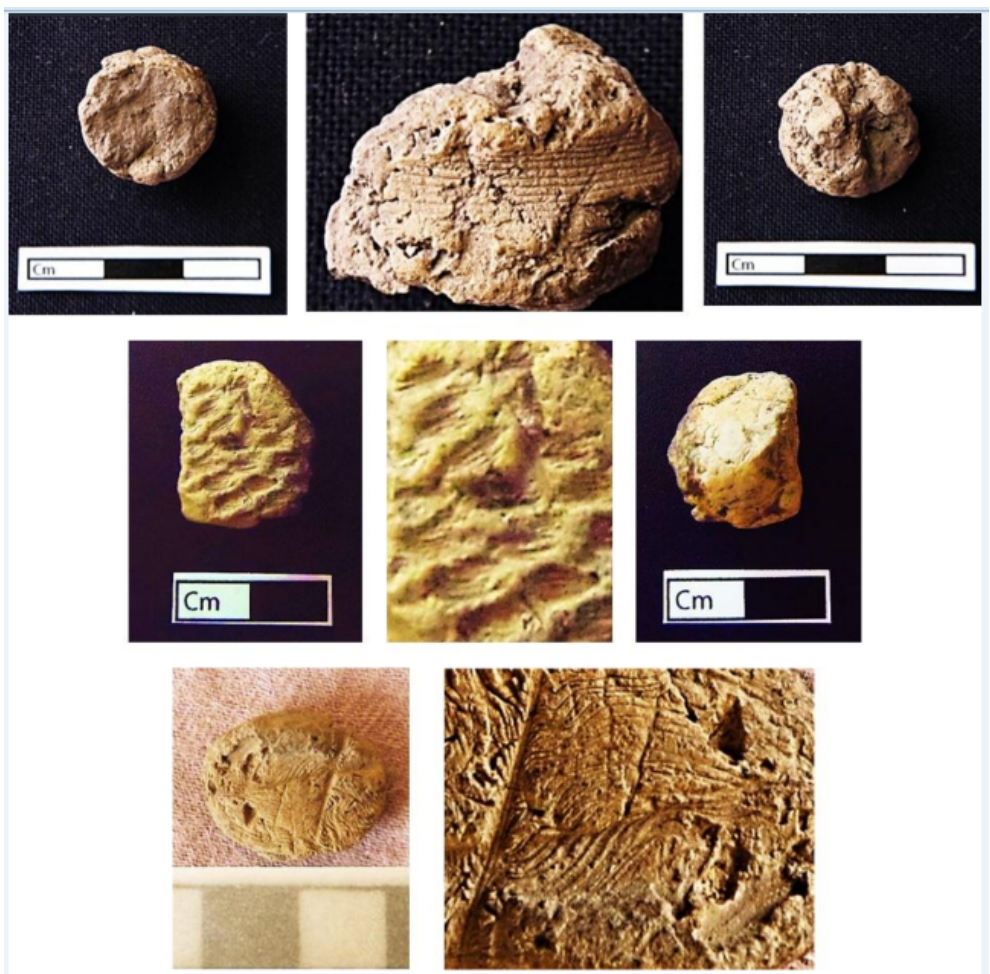

Figure 6. Examples of clay objects from Boncuklu Höyük with impressions. (Above) CO\# 1347; (centre) CO\# 2785; (below) CO\# 656. (Photographs: author.)

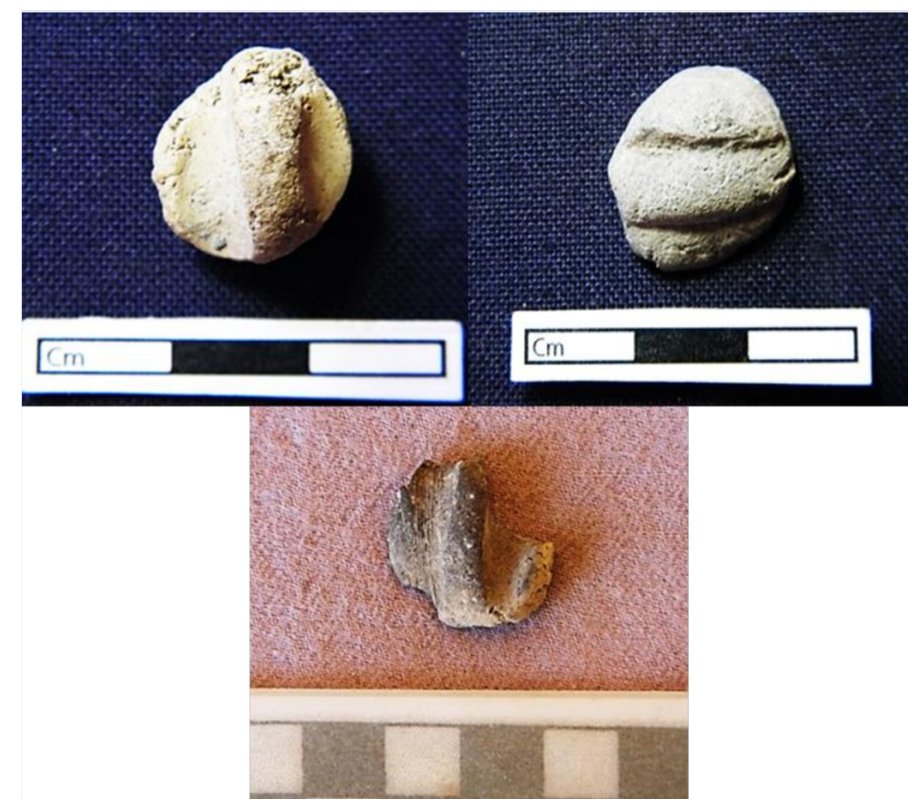

Figure 7. Three different clay objects from Boncuklu Höyük, each displaying similar markings, size, colour and shape. Left to right: CO\#s 1508, 871 \& 1465. (Photographs: author.) 


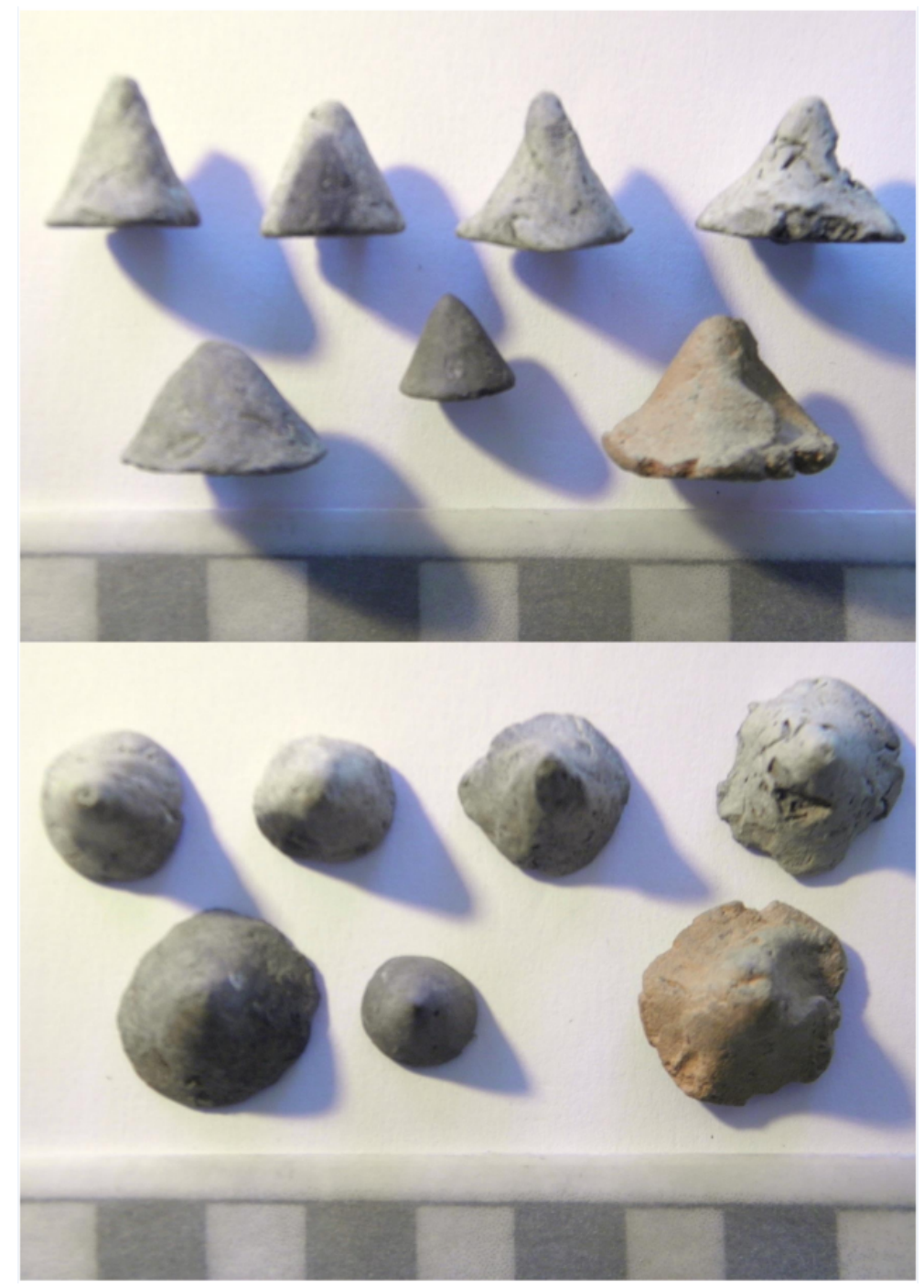

Figure 8. Selection of Çatalhöyük objects from distinctive cone set ' $B$ '. (Left to right, top to bottom) CO\#s 1171120, 1080, 1151 \& 1084. (Photograph: author.) 

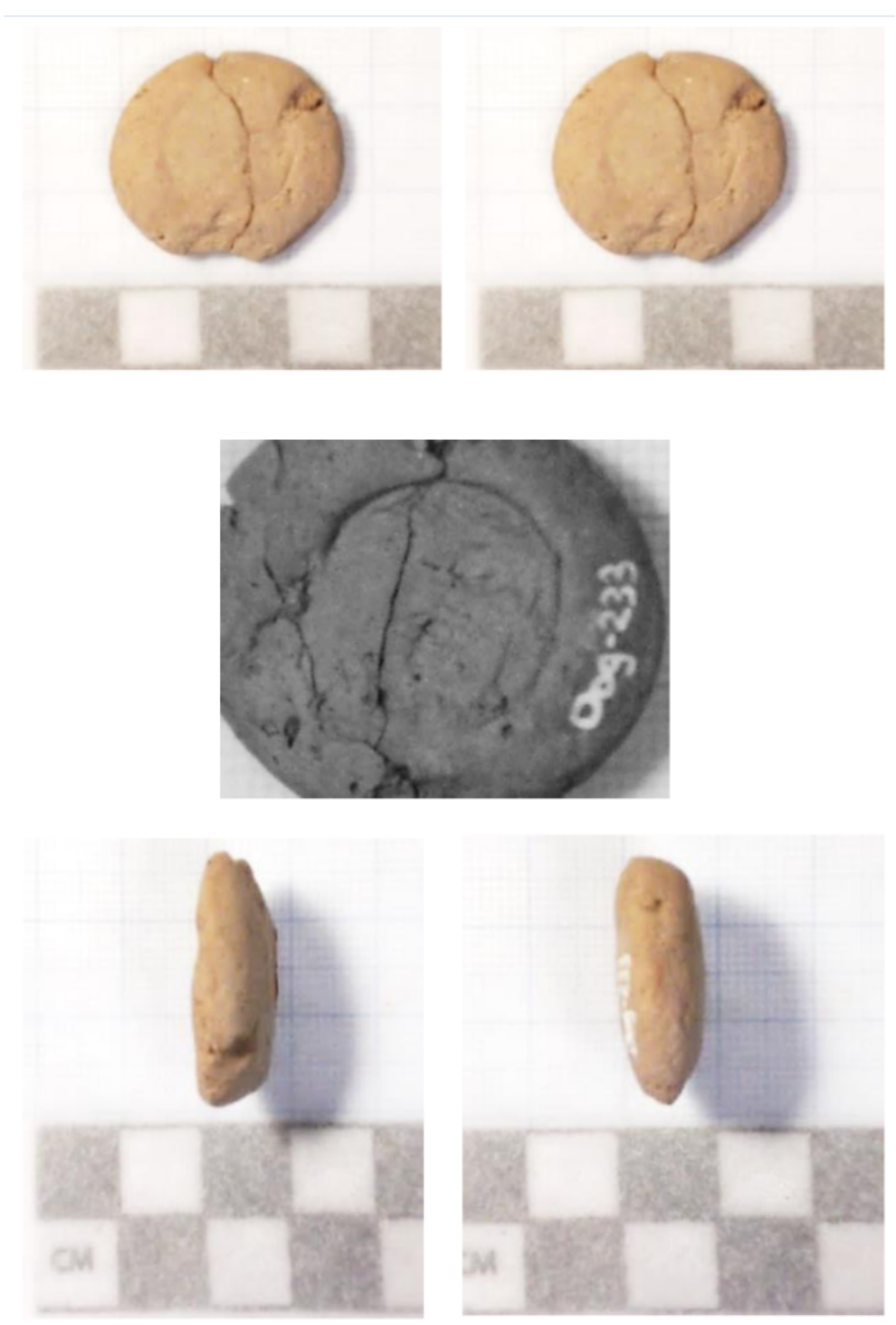

Figure 9. Disc-shaped CO\# 105, stamped on both sides. Tell Sabi Abyad tier 1 collection. (Above) Front and reverse sides; (centre) Front side in black and white with detail of impression; (below) Section and longitudinal view. (Photograph: author.) 


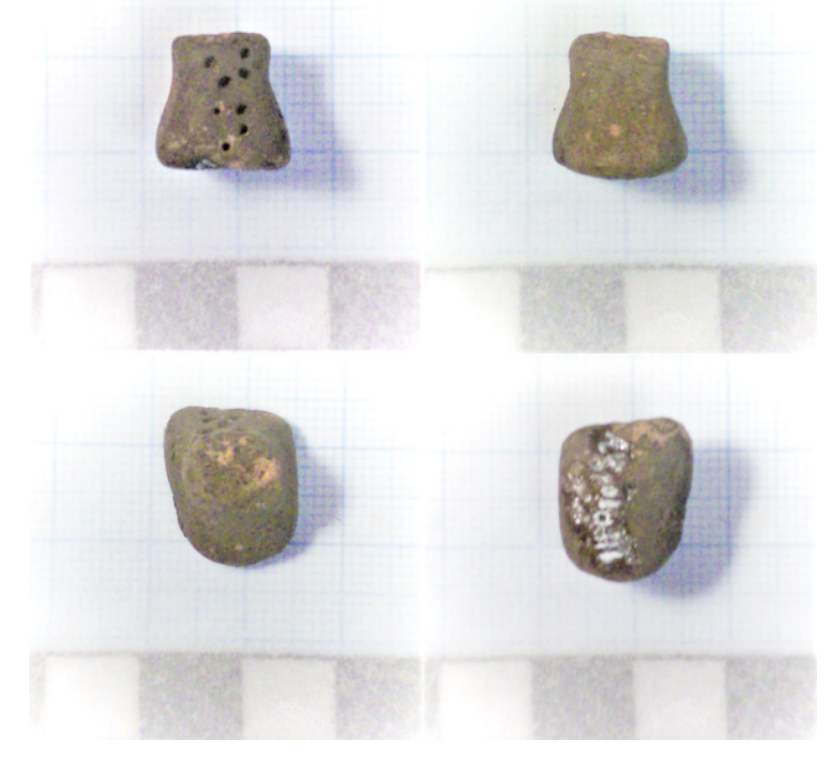

Figure 10. CO\# 226, truncated cone with square base, Tell Sabi Abyad. (Above) Front and back; (below) Viewed from above (plan view) and base. (Photographs: author.)

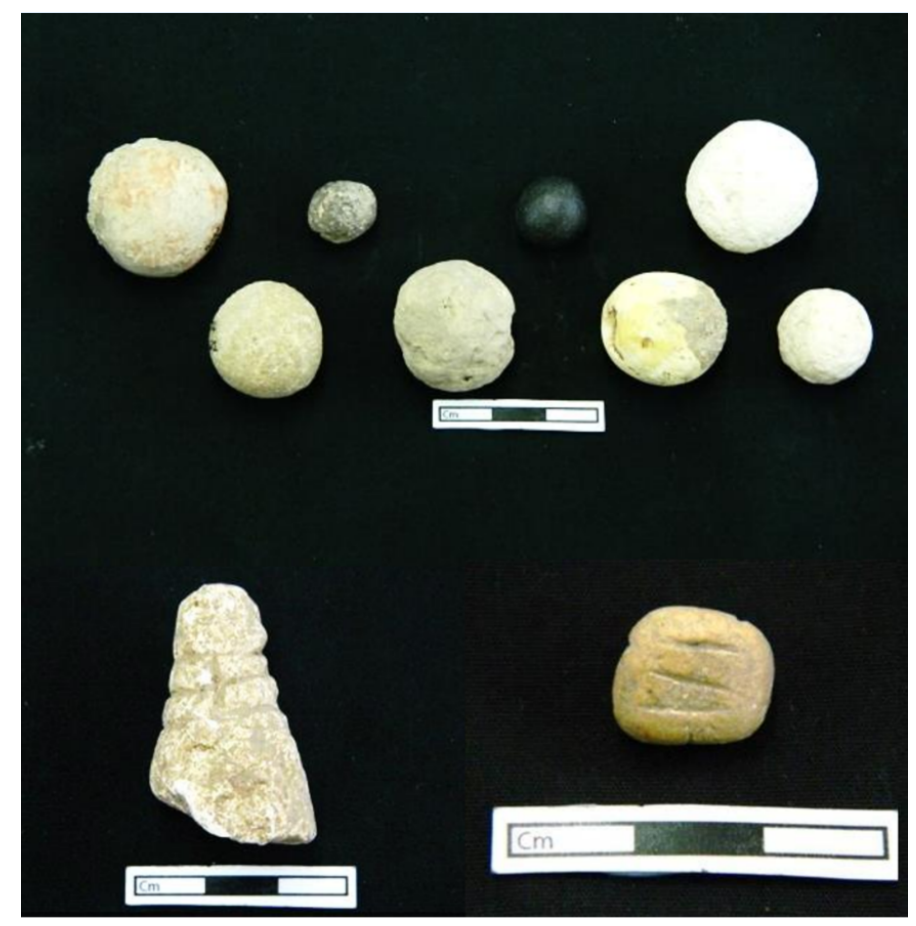

Figure 11. (Above) Selection of 'Ain Ghazal spheres from the total of 11 that were viewed (left to right, top to bottom: CO\#s 1693, 1697, 1694, 1701, 1712, 1713, 1715 and 1718); (below) Incised objects at 'Ain Ghazal: (left) Incised limestone cone (CO\#1700); (right) Incised pebble (CO\#1711). (Photographs: author, courtesy of Z. Kafafi and G. Rollefson of the 'Ain Ghazal Project.) 
Table 1. Sites from which collections of small, geometric clay objects were studied: detail (by tier) of recording: count, method of data collection and study output. C.O.D.=Clay Object Database.

\begin{tabular}{|c|c|c|c|}
\hline Site & Object count & Source & Output \\
\hline \multicolumn{4}{|c|}{ Tier 1: Direct observation case studies (3 sites) } \\
\hline Boncuklu Höyük & 672 & All recorded in person: site visits & C.O.D. \\
\hline Çatalhöyük & 695 & $\begin{array}{l}\text { Site visits }(\mathrm{n}=678) . \mathrm{n}=17 \text { (stone) objects } \\
\text { recorded from site's Groundstone } \\
\text { Database and information from } \\
\text { ground stone specialist }\end{array}$ & C.O.D. \\
\hline Tell Sabi Abyad & 393 & $\begin{array}{l}\text { Primarily recorded in person: site visit } \\
(\mathrm{n}=293) .100 \text { additional objects } \\
\text { recorded from unpublished site } \\
\text { records and publications }\end{array}$ & C.O.D. \\
\hline \multicolumn{4}{|c|}{ Tier 2: Museum collection and publication (20 sites) } \\
\hline 'Ain Ghazal & 163 & $\begin{array}{l}\text { Primarily from publication }(\mathrm{n}=137) . \\
\mathrm{n}=26 \text { geometrics were recorded in } \\
\text { person (Yarmouk University, Amman, } \\
\text { Jordan) }\end{array}$ & C.O.D. \\
\hline Aşikli Höyük & 5 & Publication & C.O.D. \\
\hline Canhasan I & 2 & Publication & C.O.D. \\
\hline Çayönü & 38 & Publication & C.O.D. \\
\hline Dermirköy & 4 & Publication & C.O.D. \\
\hline ‘Es-Sifiya & 78 & Publication & C.O.D. \\
\hline Gesher & 3 & Publication & C.O.D. \\
\hline Hajji Firuz T. & 28 & Publication & C.O.D. \\
\hline Hakemi Use & 5 & Publication & C.O.D. \\
\hline Höyücek & 25 & Publication & C.O.D. \\
\hline Jarmo & 620 & Publication & C.O.D. \\
\hline Jericho & 24 & Publication & C.O.D. \\
\hline Salat Camii Yani & 15 & Publication & C.O.D. \\
\hline Sarab & 37 & Publication & C.O.D. \\
\hline Suberde & 59 & Publication & C.O.D. \\
\hline T. Arpachiyah & 20 & British Museum (London, UK) & C.O.D. \\
\hline Tell Halaf & 7 & British Museum (London, UK) & C.O.D. \\
\hline Tell Hemmeh & 2 & Publication & C.O.D. \\
\hline Tell Kurdu & 11 & Publication & C.O.D. \\
\hline Ulucak Höyük & 12 & Publication & C.O.D. \\
\hline \multicolumn{4}{|c|}{ Tier 3: General description in literature (56 sites) } \\
\hline Various & $\mathrm{n} / \mathrm{a}$ & Publications & \begin{tabular}{|l} 
Site \\
database
\end{tabular} \\
\hline
\end{tabular}

